\title{
Representing Climate and Extreme Weather Events in Integrated Assessment Models: A Review of Existing Methods and Options for Development
}

\author{
C.M. GOODESS ${ }^{1}$, C. HANSON ${ }^{1}$, M. HULME ${ }^{2}$ AND T.J. OSBORN ${ }^{1,2}$ \\ ${ }^{1}$ Climatic Research Unit, School of Environmental Sciences, University of East Anglia, Norwich, NR4 7TJ, UK \\ and ${ }^{2}$ Tyndall Centre for Climate Change Research, School of Environmental Sciences, University of East Anglia, Norwich, NR4 7TJ, UK
}

\begin{abstract}
The lack of information about future changes in extreme weather is a major constraint of Integrated Assessment Models (IAMs) of climate change. The generation of descriptions of future climate in current IAMs is assessed. We also review recent work on scenario development methods for weather extremes, focusing on those issues which are most relevant to the needs of IAMs. Finally, some options for implementing scenarios of weather extremes in IAMs are considered.
\end{abstract}

Keywords: Integrated Assessment Models, climate change, scenarios, extreme weather events, general circulation models, regional climate models.

\section{INTEGRATED ASSESSMENT AND CLIMATE CHANGE}

One of the essential characteristics of integrated assessment is the simultaneous consideration of the multiple dimensions of environmental problems such as climate change. A number of formal integrated assessment models (IAMs) for climate change have been developed over the last decade, starting with the models IMAGE 1.0 and ESCAPE in the early 1990s [1, 2]. These models were constructed using modules that are reduced-form versions of more complex models, for example of the climate system, the economy and ecosystems. Most climate modules in IAMs generate zero (i.e., globally-averaged; e.g., PAGE) or one (i.e., zonallyaveraged; e.g., IMAGE) dimensional descriptions of future climate, usually at a mean (e.g., 30-year average) seasonal or annual resolution [3-5]. Some IAMs (e.g., IMAGE 2.2 and AIM) then generate spatially explicit, i.e., two-dimensional, descriptions of future climate, usually by accessing stored patterns of climate change derived from more complex General Circulation Model (GCM) experiments [6-8].

These approaches to generating future climate descriptions in IAMs, which are reviewed in Section 2, are computationally efficient and allow multiple experiments to be easily conducted in an integrated framework. The climate output is then input into an ecosystem, agriculture or health impacts module (e.g., AIM), or used directly to estimate the economic cost of climate damage from a lookup climate damage function (e.g., DICE). In either case, the current lack of any information about changes in daily or extreme weather (the focus of this review) is a major weakness. Agriculture, for example, is likely to be as, or more, sensitive to changes in daily weather sequences and the occurrence of extreme weather events than to changes in mean monthly or seasonal climate [9-11]. Potential changes in extremes and the ensuing changes in risk are also important for sectors such as water resources and insurance $[12,13]$. Climate damage functions that express the economic impact of climate change as a function of global- (or regional-) mean climate alone are likely to underestimate the economic damage associated with extreme events such as flooding and storms (e.g., in the UK, the October 1987 windstorm event is estimated to have cost insurers 3.1 billion US dollars, with further economic losses of 2.7 billion US dollars [14]). The lack of information about changes in daily weather and extreme events also limits simulation of adaptive processes in social institutions and environmental systems: an important objective of the emerging third generation of IAMs [15].

Identification and definition of the weather extremes which should be considered in IAMs is not straightforward, although a number of indicators of temperature (e.g., 90th 
percentile, frost severity index, heat wave duration index) and precipitation (e.g., 90th percentile/quantile, maximum length of wet/dry spell, magnitude of the 20 year return period event) weather extremes have recently been recommended for use in climate-change studies $[12,16]$. Appropriate temporal and spatial scales also need to be identified [17]. It is generally assumed that information at the daily time scale is necessary to investigate extreme events. However, extreme events such as drought (e.g., the 1976 multi-season drought in the UK) can usefully be defined using monthly data and at the regional spatial scale (e.g., greater than $1000 \mathrm{~km}^{2}$ for the UK). Intense rainfall events leading to flooding are more appropriately investigated at higher resolutions (e.g., durations of 12-72 hours and spatial scales of about $100 \mathrm{~km}^{2}$ are relevant in Scotland).

For many impact sectors it may be necessary to consider other variables, such as wind, hail, fog, lightning and storm surges. Joint probability events may also be important (e.g., wind storms with snow/rain, heavy snow followed by rapid thaw, coastal storm surge with river flood), together with changes in the persistence and sequence of extreme events (e.g., sequences of long dry/hot summers) and seasonal changes in the timing of extremes (e.g., changes in the season of maximum frequency of occurrence). Finally, a distinction needs to be made between meteorological information on extremes (i.e., statistics concerning their frequency and magnitude) and their impacts. What, for example, is the relationship between the 99th percentile precipitation event and the 1 in 100-year flood event? And how might this relationship be affected by factors such as land-use change? It should also be noted that some weather events may be extreme in terms of their impact, although the weather event itself is not extreme (e.g., for air quality and building comfort, 'non-events' such as very low wind speed may be important). Thus, even for single-sector climate impacts studies, the incorporation of changes in weather extremes is potentially complex and places additional demands on scenario development methods compared with changes in mean climate. In IAMs, these complexities must be balanced against the need for computational efficiency (see Section 4).

Recent work on scenario development methods for weather extremes is reviewed in Section 3, focusing on temperature and precipitation extremes and the issues which are most relevant to the needs of integrated assessment modelling. Ways in which these methods could be implemented in IAMs in order to overcome one of the shortcomings of the current generation of IAMs, i.e., the failure to represent extreme weather events, are discussed in Section 4, focusing on the UK and European perspectives.

Together with the growing recognition of the need to incorporate information about changes in interannual climate variability and the occurrence of extremes into integrated assessments, there is also growing concern to take into account the full range of uncertainties in scenario construction and, at the same time, to distinguish between the inherent unpredictability of climate and climate model deficiencies [18-29]. The IPCC Third Assessment Report (TAR) [30, 31] and many of the references cited above, refer to a cascade of climate prediction uncertainty related to:

- the forcing emissions scenarios, i.e., inter-scenario variability;

- the response of different climate models, i.e., inter-model variability;

- different realizations of a given forcing scenario with a given climate model, i.e., internal model variability (which is, in part, a reflection of natural climate variability); and,

- sub-grid scale forcings and processes.

Appropriate techniques for handling the first three sources of uncertainty are widely recognised (see references above, also [32-38]), although they are not yet routinely or comprehensively applied in impacts assessments. Thus,

- uncertainties due to inter-scenario variability can be handled by using more than one forcing scenario;

- uncertainties due to inter-model variability can be handled by using output from more than one climate model; and,

- uncertainties due to internal model variability and thus, in part, natural climate variability, can be handled by using single-model ensembles (i.e., simulations performed with the same climate models and forcing, but starting from different initial conditions).

The application of these techniques in IAMs is reviewed in Section 2.7, while the additional issues that arise in applying them to extremes, together with the less-widely addressed problem of uncertainties arising from sub-grid scale forcings and processes, are discussed briefly in Section 3.5.

The IPCC Second Assessment Report (SAR) [39] concluded that one of the biggest challenges facing integrated assessment was the consideration, assessment and incorporation of low probability/high consequence events into IAMs. This need was re-emphasised by the Third Assessment Report [31] which identifies events such as "abrupt" reorganisation of the thermohaline circulation and the collapse of the West Antarctic ice sheet that could arise due to non-linearities in the climate system. Reviewing knowledge of such events is beyond the scope of this paper, although it is noted that the DICE and ICLIPS IAMs have been used to explore abrupt thermohaline circulation changes [40-44]. Future integrated assessments of these changes will benefit from ongoing research on (i) the conditional probability of the event occurring, and (ii) the response of the climate system to the event.

The focus of this paper is climate and extreme weather events. Thus potential problems relating to the representation of social, economic and technological aspects, and the associated feedbacks, are not discussed. 


\section{THE TREATMENT OF CLIMATE IN IAMs}

\subsection{The Development of IAMs}

The criterion used to determine whether a model is 'integrated' is subjective. The problem stems from the fact that IAMs are supposedly all encompassing; replicating not only the primary dynamic interactions between society and environment, but also the secondary feedback mechanisms. In trying to embrace all aspects of environmental change, the developers of such models have to make decisions about the focus of their study and how they wish to express the impacts they are attempting to estimate, whether this be through the reporting of physical changes in emissions, shifts in landuse activity or mortality rates, or through cost-benefit analysis of damages resulting from climate change [39]. This in many cases leads to certain components or modules within the IAM - those most closely linked to the exposure unit being studied - being more complex than those other modules that are included in the IAM in order to close the loop.

The origins of integrated assessment modelling lie with the "Club of Rome" models developed in the 1970s. These used a holistic approach to look at issues such as resource depletion, population growth and environmental pollution [45]. The late 1970s saw the development of formallymodelled integrated assessments of energy policy. The role of such models in environmental policy formation was further enhanced in the early 1980s when the RAINS model played a key part in the process that brought about a European-wide agreement to control acid rain [46]. But, while many environmental issues were explored using an integrated approach, climate change impact assessment studies carried out during the 1980s tended to be more focused in nature, looking only at single exposure units.

The earliest integrated global climate change models were conceived in the late 1980s, when the first model to fully encompass energy, climate and impacts was IMAGE 1.0 [1]. At the regional level, the MINK project [47] and the Atmospheric Stabilisation Framework (ASF) were initiated to examine the problem of climate change in an integrated way and looked at climate impacts on sectors such as forestry, agriculture and water resources [39].

The early 1990s witnessed the development of several global and regional integrated climate change models. IMAGE reached version 2 and a European consortium developed the ESCAPE model. As the models became more complex, so the size and nature of the modelling effort changed, from models such as DICE, PAGE and FUND developed by individuals, to models such as IMAGE 2.2 developed by whole research institutes and eventually to models such as ICLIPS developed by research networks spanning continents. The representation of climate in these IAMs has become more sophisticated and diverse over time. Methods used in the current generation of IAMs are reviewed in the next section.

\subsection{Representation of Climate in the Currently-used Second Generation of IAMs}

Here, thirteen of the more established climate change IAMs (Table 1) which illustrate the different approaches to integrated assessment modelling are reviewed. The IAM literature is extensive and the list of models in Table 1 is not exhaustive. However, it encompasses all the internationally better known IAMs. All listed IAMS are referenced in the IPCC SAR and TAR and some have been used most recently to investigate the impacts associated with the SRES marker scenarios [48]. The focus here is on how they use observed climatologies and climate model projections: summarised in Table 2. It is immediately apparent that the type of climate data and models utilised by each IAM is highly dependent on its particular focus, i.e., economic costs and benefits, biophysical impacts, policy guidance or adaptation.

The aim of the climate model component of any IAM is to produce plausible future climates, linked to prior emissions, in order to assess the impacts of climate change. Two approaches are taken (Fig. 1). The first approach, used in IAMs focusing on economic costs and benefits, is to estimate global temperature between two time periods and the second approach, used in IAMs focusing on biophysical impacts, is to perturb observed baseline regional climatologies using climate model output.

The majority of IAMs adopt the second approach, i.e., future climate is constructed by combining an observed baseline climatology with future regional climate change patterns produced by GCMs, scaled using estimates of changes in global mean temperature generated by Simple Climate Models (SCMs) such as COSMIC [49, 50] or MAGICC [51]. This approach is typified by the IMAGE model [52] in which future greenhouse gas emissions are calculated by the energy-industry module for each economic region as a function of energy consumption and industrial production. These emissions are combined with emissions released from the terrestrial biosphere to the atmosphere which are produced by the terrestrial-environment module (which simulates land use and land-cover dynamics for a $0.5^{\circ} \times 0.5^{\circ}$ grid). The combined emissions are globally aggregated and then input into a SCM, in this case an upwelling-diffusion model based on MAGICC. The output from this module is used to scale the regional climate change pattern, which is then added to the 1961-1990 baseline climatology.

CETA, DICE, FUND, ICAM-3, MERGE, MiniCAM and PAGE95 all adopt the first approach, i.e., they use an observed reference point, rather than a baseline climatology, from which to calculate changes in atmospheric greenhouse gas concentrations and global temperature. These models tend to operate at the global level, using SCM output to produce an aggregated average global change in climate. This approach is illustrated by MERGE. Future concentrations of greenhouse gases $\left(\mathrm{CO}_{2}, \mathrm{CH}_{4}\right.$ and $\left.\mathrm{N}_{2} \mathrm{O}\right)$ are simulated 
Table 1. Model names, developers and key references for the 13 IAMs reviewed in the paper.

\begin{tabular}{|c|c|c|}
\hline Model & Developers & Key references \\
\hline \multicolumn{3}{|l|}{ Cost-benefit analysis models } \\
\hline CETA & EPRI and Teisberg Associates, USA & {$[4,66,170]$} \\
\hline DICE & Nordhaus, Yale University, USA & {$[171]$} \\
\hline \multicolumn{3}{|l|}{ Related models: } \\
\hline \multicolumn{3}{|l|}{ PRICE } \\
\hline \multicolumn{3}{|l|}{ RICE } \\
\hline FUND & RSJ Tol, University of Hamburg & {$[5,68]$} \\
\hline ICAM-3 & Carnegie Mellon University, USA & {$[172,173]$} \\
\hline MERGE 4.4 & Stanford University, USA & http://www.stanford.edu/group/MERGE/ [53, 67] \\
\hline MiniCAM & $\begin{array}{l}\text { Global Change Group at Pacific Northwest } \\
\text { Laboratory, USA. }\end{array}$ & $\begin{array}{l}\text { http://www.grida.no/climate/ipcc/emission/ } \\
\text { 154.htm } \\
\text { http://sedac.ciesin.org/mva/MCPAPER/ } \\
\text { mcpaper.html }[174,175]\end{array}$ \\
\hline PAGE95 & $\begin{array}{l}\text { Judge Institute of Management Studies, } \\
\text { University of Cambridge, UK }\end{array}$ & {$[3,85]$} \\
\hline \multicolumn{3}{|l|}{ Biophysical-impacts models } \\
\hline AIM & $\begin{array}{l}\text { National Institute for Environmental Studies, } \\
\text { Japan and Kyoto University }\end{array}$ & http://www-cger.nies.go.jp/ipcc/aim/ [6] \\
\hline CLIMPACTS & International Global Change Institute (IGCI), & http://www.waikato.ac.nz/igci/ \\
\hline $\begin{array}{l}\text { Related models: OzCLIM, } \\
\text { BDCLIM, VANDACLIM }\end{array}$ & University of Waikato, New Zealand & climpacts_webpage/ [83] \\
\hline ESCAPE & $\begin{array}{l}\text { Climatic Research Unit, UK and RIVM, } \\
\text { The Netherlands }\end{array}$ & {$[2,54]$} \\
\hline IMAGE 2.2 & RIVM, The Netherlands & $\begin{array}{l}\text { http://www.rivm.nl/image/home.html } \\
\quad[52,176]\end{array}$ \\
\hline MIT IGSM & $\begin{array}{l}\text { Joint Program on the Science and Policy of } \\
\text { Global Change, Massachusetts Institute } \\
\text { of Technology, USA }\end{array}$ & $\begin{array}{l}\text { http://web.mit.edu/globalchange/www/if.html } \\
\quad[8,177]\end{array}$ \\
\hline \multicolumn{3}{|l|}{ Tolerable windows approach } \\
\hline ICLIPS & $\begin{array}{l}\text { Potsdam Institute for Climate Impact } \\
\text { Research (PIK), Germany }\end{array}$ & $\begin{array}{l}\text { http://www.pik-potsdam.de/cp/iclips } \\
{[43,75,79]}\end{array}$ \\
\hline
\end{tabular}

and then the change in temperature calculated relative to 2000. The global equilibrium (surface) temperature change $(\triangle P T)$ is calculated by aggregating the radiative effects $(\Delta F)$ of $\mathrm{CO}_{2}, \mathrm{CH}_{4}$ and $\mathrm{N}_{2} \mathrm{O}$ :

$$
\triangle P T=d^{*} \Delta F
$$

where: $d$ determines the equilibrium climate sensitivity (assumed to be $0.555^{\circ} \mathrm{CW} \mathrm{m}^{2}$ in MERGE) and $\Delta F=$ $\Delta \mathrm{F}_{\mathrm{CO}_{2}}+\Delta \mathrm{F}_{\mathrm{CH}_{4}}+\Delta \mathrm{F}_{\mathrm{N}_{2} \mathrm{O}}$.

Actual temperature change, $\triangle A T$, is then calculated:

$$
\Delta A T_{t+1}-\Delta A T_{t}=c_{1}^{*}\left(\Delta P T_{t}-\Delta A T_{t}\right)
$$

where: $c_{1}=0.05$ (representing a 20 year mean lag to reflect the slower warming of the oceans) and $\triangle A T_{t}$ is the actual temperature change in year $t$ relative to 2000 [53].

One of the greatest challenges for IAMs is that the climatic conditions need to be calculated online. A technique that is commonly used to generate a large range of climate scenarios internally is pattern-scaling. SCENGEN [54] and COSMIC [49, 50] are widely used pattern-scaling tools. Pattern-scaling works by standardising the climate change pattern derived from a GCM by dividing by the global mean warming for a particular climate change experiment, which then expresses the climate change per ${ }^{\circ} \mathrm{C}$ global warming [55-60]. The standardised pattern can then be re-scaled using the global temperature change simulated under any other scenario by an SCM such as MAGICC. A typical twostage approach for temperature is illustrated in Equations 3 and 4 [61].

$$
\left(\frac{T_{i 2 x C O_{2}}-T_{i 1 x C O_{2}}}{\Delta T_{2 x}}\right)=\Delta T_{i}^{*}
$$

where:

$\Delta T_{2 x}=$ Equilibrium GCM climate sensitivity

$T_{i 1 x \mathrm{CO}_{2}}=$ Temperature for $1 \times \mathrm{CO}_{2}$ experiments at grid point $i$

$T_{i 2 x \mathrm{CO}_{2}}=$ Temperature for $2 \times \mathrm{CO}_{2}$ experiments at grid point $i$

$\Delta T_{i}^{*}=$ Standardised temperature change value for grid point $i$ from a GCM experiment

The actual climate change scenario is then constructed by:

$$
\Delta T_{i}^{*} \times \mathrm{MAGICC} \Delta T_{\text {year }}
$$

where:

MAGICC $\Delta \mathrm{T}_{\text {year }}=$ the global-mean temperature change for a given year with respect to 1990 . 
Table 2. Summary of how the 13 IAMs reviewed in the paper use observed climatologies and climate model projections.

\begin{tabular}{|c|c|c|c|c|c|c|}
\hline Model & $\begin{array}{l}\text { Geographical } \\
\text { Focus of IAM }\end{array}$ & No. of Emissions Regions ${ }^{\mathrm{a}}$ & $\begin{array}{c}\text { Baseline } \\
\text { Climatology/ } \\
\text { Reference Data }\end{array}$ & $\begin{array}{l}\text { Simple Climate Model } \\
\text { (SCM) Description }\end{array}$ & $\begin{array}{l}\text { Description of internally } \\
\text { calculated climate change } \\
(\Delta \mathrm{C}) \text { variables }\end{array}$ & $\begin{array}{l}\text { Treatment of } \\
\text { uncertainty }\end{array}$ \\
\hline \multicolumn{7}{|c|}{ Cost-benefit analysis models } \\
\hline CETA & $\begin{array}{l}\text { Global and } \\
2 \text { regions }\end{array}$ & $\begin{array}{l}1 \text { - Global or } 2 \text { - OECD } \\
\text { plus the Commonwealth } \\
\text { of Independent States and } \\
\text { Eastern Europe, Rest of } \\
\text { World. }\end{array}$ & $\begin{array}{l}\text { Global temperature } \\
\text { at pre-industrial } \\
\text { levels. }\end{array}$ & $\begin{array}{l}\text { Global } 2100 \text { model [179] } \\
\text { incorporating a global } \\
\text { warming module and } \\
\text { adaptation/damage cost } \\
\text { function representing } \\
\text { damage from warming. }\end{array}$ & $\begin{array}{l}1990-2200 \text { at } 10-y r \text { intervals. } \\
\text { Global temperature change } \\
\text { related to temperature at } \\
\text { pre-industrial levels. }\end{array}$ & $\begin{array}{l}\text { Sensitivity analysis of } \\
\text { changes to various } \\
\text { parameters within } \\
\text { the IAM. Use of } \\
\text { different climate } \\
\text { sensitivities ranging } \\
\text { from } 1-5^{\circ} \mathrm{C}\end{array}$ \\
\hline DICE & Global & 1 - Global & $\begin{array}{l}\text { Temperature only. } \\
\text { Historical time } \\
\text { series of annual } \\
\text { averages 1862- } \\
1989 \text { [180] }\end{array}$ & $\begin{array}{l}\text { 1965-2105. Box-Advection } \\
\text { Model. SCM calibrated } \\
\text { against historical } \\
\text { temperature series } \\
1862-1989 \text { [180] and } \\
\text { runs of } 3 \text { GCMs [181-183]. }\end{array}$ & $\begin{array}{l}1965-2105 \text { at } 10-y r \text { intervals. } \\
\text { Global temperature change. }\end{array}$ & $\begin{array}{l}\text { Stochastic treatment } \\
\text { of uncertainty } \\
\text { utilising Monte } \\
\text { Carlo distributions } \\
\text { of the IAM } \\
\text { parameters. Use } \\
\text { of different climate } \\
\text { sensitivities. }\end{array}$ \\
\hline FUND & $\begin{array}{l}\text { Global and } \\
9 \text { regions }\end{array}$ & $\begin{array}{l}9 \text { - OECD-America, OECD- } \\
\text { Europe, OECD-Pacific, } \\
\text { Central and Eastern Europe } \\
\text { and the Former Soviet Union, } \\
\text { Middle East, Latin America, } \\
\text { South and Southeast Asia, } \\
\text { Centrally Planned Asia, Africa. }\end{array}$ & $\begin{array}{l}\text { Observed global } \\
\text { annual average } \\
\text { temperature } \\
\text { time series from } \\
1950 \text { to } 1990 . \\
\text { (IMAGE database: } \\
\text { [184]). }\end{array}$ & $\begin{array}{l}\text { FUND consists of a set of } \\
\text { exogenous scenarios and } \\
\text { endogenous perturbations, } \\
\text { [68] }\end{array}$ & $\begin{array}{l}\text { 1950-2200. Global temperature } \\
\text { change at 1-yr intervals. } \\
\text { Global temperature change. } \\
\text { Area weighted average } \\
\text { regional temperature } \\
\text { increase is used to } \\
\text { approximate mean } \\
\text { global temperature } \\
\text { increase. }\end{array}$ & $\begin{array}{l}\text { Stochastic treatment } \\
\text { of uncertainty } \\
\text { utilising probability } \\
\text { distributions of the } \\
\text { IAM parameters. }\end{array}$ \\
\hline ICAM-3 & $\begin{array}{l}\text { Global and } \\
12 \text { regions }\end{array}$ & $\begin{array}{l}12 \text { - US and Canada, Western } \\
\text { Europe, China and East Asia, } \\
\text { Eastern Europe, India and } \\
\text { South Asia, Southeast Asia, } \\
\text { North Asia, C and S Africa, } \\
\text { North Africa and the Middle } \\
\text { East, Latin America, Australia } \\
\text { and New Zealand, Japan. }\end{array}$ & $\begin{array}{l}\text { Temperature. Model } \\
\text { initialised with a global } \\
\text { temperature anomaly } \\
\text { drawn from a normal } \\
\text { distribution with a } \\
\text { mean of } 0.4 \mathrm{~K} \text { and } \\
\text { standard deviation } 0.3 \mathrm{~K} \text {. } \\
\text { This is based on the IPCC } \\
\text { consensus that global } \\
\text { temperature change from } \\
\text { pre-industrial times to } \\
1995 \text { was in the range } \\
\text { of } 0.3 \text { to } 0.5 \mathrm{~K} \text {. }\end{array}$ & $\begin{array}{l}\text { Global temperature response } \\
\text { to a perturbation in the } \\
\text { greenhouse gas radiative } \\
\text { forcing. A simple model } \\
\text { is used to achieve } \\
\text { temperature change } \\
\text { consistent with observed } \\
\text { energy transport from } \\
\text { equator to pole [185]. } \\
\text { Local temperature } \\
\text { anomalies are adjusted } \\
\text { based on the radiative } \\
\text { cooling due to regional } \\
\text { aerosols. }\end{array}$ & $\begin{array}{l}\text { 1975-2100. Temperature } \\
\text { at 5-yr intervals. Can } \\
\text { be divided into an } \\
\text { arbitrary number of } \\
\text { latitudinal bands to } \\
\text { estimate regional } \\
\text { temperature change. } \\
\text { The regional model } \\
\text { uses } 7 \text { latitudinal } \\
\text { bands: } 90-75^{\circ} \mathrm{N} \text {; } \\
75-50^{\circ} \mathrm{N}: 50-30^{\circ} \mathrm{N} \text {; } \\
30^{\circ} \mathrm{N}-0^{\circ} ; 0^{\circ}-30^{\circ} \mathrm{S} ; \\
30-55^{\circ} \mathrm{S} ; 55-90^{\circ} \mathrm{S} \text {. } \\
\text { The middle five bands } \\
\text { cover the } 12 \mathrm{UN} \text {-defined } \\
\text { regions. }\end{array}$ & $\begin{array}{l}\text { Stochastic treatment } \\
\text { of uncertainty } \\
\text { utilising probability } \\
\text { distributions of the } \\
\text { IAM parameters. } \\
\text { Sensitivity analysis } \\
\text { of changes to } \\
\text { various IAM } \\
\text { parameters. }\end{array}$ \\
\hline
\end{tabular}


Table 2. (continued).

\begin{tabular}{|c|c|c|c|c|c|c|}
\hline Model & $\begin{array}{l}\text { Geographical } \\
\text { Focus of IAM }\end{array}$ & No. of Emissions Regions ${ }^{\mathrm{a}}$ & $\begin{array}{c}\text { Baseline } \\
\text { Climatology/ } \\
\text { Reference Data }\end{array}$ & $\begin{array}{l}\text { Simple Climate Model } \\
\text { (SCM) Description }\end{array}$ & $\begin{array}{l}\text { Description of internally } \\
\text { calculated climate change } \\
(\Delta \mathrm{C}) \text { variables }{ }^{\mathrm{b}}\end{array}$ & $\begin{array}{l}\text { Treatment of } \\
\text { uncertainty }\end{array}$ \\
\hline MERGE 4.4 & $\begin{array}{l}\text { Global and } \\
9 \text { regions }\end{array}$ & $\begin{array}{l}9 \text { - USA, OECDE (Western } \\
\text { Europe), Japan, CANZ } \\
\text { (Canada, Australia, New } \\
\text { Zealand), EEFSU (Eastern } \\
\text { Europe and the Former } \\
\text { Soviet Union), China, India, } \\
\text { MOPEC (Mexico and OPEC), } \\
\text { ROW (Rest of World) }\end{array}$ & $\begin{array}{l}\text { Global temperature } \\
\text { at } 2000 .\end{array}$ & $\begin{array}{l}\text { The SCM is composed of } \\
\text { the Global } 2200 \text { emissions } \\
\text { model which then inputs } \\
\text { into the climate submodel. } \\
\text { The SCM therefore represents } \\
\text { atmospheric lifetimes of the } \\
\text { three main greenhouse gases } \\
\text { and then yields a global } \\
\text { change in radiative forcing } \\
\text { and global average } \\
\text { temperature change. }\end{array}$ & $\begin{array}{l}2000 \text { to } 2200.2000-2050 \\
\text { at } 10 \text {-yr intervals and } \\
\text { then } 25 \text {-yr intervals up to } \\
2200 \text {. Global temperature } \\
\text { change only. }\end{array}$ & $\begin{array}{l}\text { Sensitivity analysis } \\
\text { of changes to } \\
\text { various IAM } \\
\text { parameters. }\end{array}$ \\
\hline MiniCAM & $\begin{array}{l}\text { Global and } \\
11 \text { regions } \\
\text { (14 region } \\
\text { version } \\
\text { nearing } \\
\text { completion) }\end{array}$ & $\begin{array}{l}11 \text { - USA, Canada, Western } \\
\text { Europe, Japan, Australia and } \\
\text { New Zealand, Eastern Europe } \\
\text { and the Former Soviet Union, } \\
\text { Centrally Planned Asia, Middle } \\
\text { East, Africa, Latin America and } \\
\text { Caribbean, South and East Asia. }\end{array}$ & $\begin{array}{l}\text { Reference period can } \\
\text { be defined by the } \\
\text { user in MAGICC - } \\
\text { default is } 1990 \text {. }\end{array}$ & $\begin{array}{l}1990 \text { to } 2095 \text {. Upwelling- } \\
\text { Diffusion Climate Model } \\
\text { (MAGICC). Emissions } \\
\text { calculations are made } \\
\text { by the ERB model for } \\
\mathrm{CO}_{2}, \mathrm{CH}_{4} \text { and } \mathrm{N}_{2} \mathrm{O} \text {. } \\
\text { Input to SCM and then } \\
\text { scaled to give regional } \\
\text { change in temperature } \\
\text { using SCENGE. }\end{array}$ & $\begin{array}{l}\text { 1990-2095 at } 15-\mathrm{yr} \text { intervals. } \\
\text { Global temperature change } \\
\text { and sea level rise. }\end{array}$ & $\begin{array}{l}\text { Use of different } \\
\text { climate sensitivities } \\
\text { ranging from } \\
1.5-4.5^{\circ} \mathrm{C}\end{array}$ \\
\hline PAGE95 & $\begin{array}{l}\text { Global and } \\
8 \text { regions }\end{array}$ & $\begin{array}{l}8 \text { - European Union, Eastern Europe } \\
\text { and the Former Soviet Union, USA, } \\
\text { other OECD nations, Africa and the } \\
\text { Middle East, China and centrally } \\
\text { planned Asia, India and Southeast } \\
\text { Asia, Latin America. (These are } \\
\text { aggregated to form a global total } \\
\text { before entry into the SCM). }\end{array}$ & $\begin{array}{l}\text { Global temperature } \\
\text { at pre-industrial } \\
\text { (1765) levels. }\end{array}$ & $\begin{array}{l}\text { 1990-2200. Reduced form } \\
\text { of the STUGE model } \\
\text { [186] updated to include } \\
\text { sulphates. }\end{array}$ & $\begin{array}{l}\text { The output interval is user } \\
\text { specified between } 1990 \text { to } \\
2200 \text {. The default is a } 20 \text {-yr } \\
\text { interval up to } 2100 \text {, and every } \\
25 \text {-yrs from } 2100 \text { to } 2200 \text {. } \\
\text { Annual global and regional } \\
\text { temperature changes. } \\
\text { Temperature rise computed } \\
\text { by relating temperature to } \\
\text { the difference in concentration } \\
\text { in the base year (1990) and the } \\
\text { pre-industrial concentration of } \\
\text { greenhouse gases to produce } \\
\text { the realised regional temperature } \\
\text { increase in each year compared } \\
\text { with the pre-industrial temperature } \\
\text { in } 1765 \text {. Area weighted average } \\
\text { regional temperature increase is } \\
\text { used to approximate mean global } \\
\text { temperature increase. }\end{array}$ & $\begin{array}{l}\text { Stochastic treatment } \\
\text { of uncertainty } \\
\text { utilising probability } \\
\text { distributions of the } \\
\text { IAM parameters. }\end{array}$ \\
\hline
\end{tabular}


Biophysical-impacts models

AIM Global an

Asian-Pacific

Region Canada, Pacific OECD, Eastern

Europe and Former Soviet Union,

China and Central Planned Asia,

South and East Asia, Middle East,

Africa, Middle and South America

CLIMPACTS New Zealand

1 - Global
920-1980 long-term monthly averages.

$0.5^{\circ} \times 0.5^{\circ}$ grids

Monthly Tmax, Tmi

solar radiation \&

precipitation

(extrapolated from

observed data: [187])

30-yr normal (19511980). $0.05^{\circ} \times 0.05^{\circ}$ grids. Monthly

Tmax, Tmin, solar

radiation \& precipi-

tation (extrapolated

from observed data) 30-yr normal (19511980). $0.5^{\circ} \times 1.0^{\circ}$ grids. Monthly

Tmean Tmax, Tmin \& precipitation (extrapolated from observed data). $\begin{array}{ll}\text { and EU nation } & \text { Union \& Rest of World (thes } \\ \text { states } & \text { aggregated to form a global t }\end{array}$ before entry into the SCM)

\begin{tabular}{|c|c|c|c|}
\hline ESCAPE & $\begin{array}{l}\text { EU } 10+15 \\
\text { and EU nation } \\
\text { states }\end{array}$ & $\begin{array}{l}4 \text { - EU, Other OECD, Former Soviet } \\
\text { Union \& Rest of World (these are } \\
\text { aggregated to form a global total } \\
\text { before entry into the SCM) }\end{array}$ & $\begin{array}{l}\text { 30-yr normal }(1951- \\
1980) .0 .5^{\circ} \times 1.0^{\circ} \\
\text { grids. Monthly } \\
\text { Tmean Tmax, Tmin } \\
\text { \& precipitation } \\
\text { (extrapolated from } \\
\text { observed data). }\end{array}$ \\
\hline
\end{tabular}

IMAGE 2.2 Global and nation state
17 - Canada, USA, Central America, Northern Africa, Western Africa,

Eastern Africa, Middle East,

South Asia, OECD Europe, Eastern

Europe, Former USSR, East Asia,

South East Asia, Japan, South America

Southern Africa, Oceania (these are

aggregated to form a global total

before entry into the SCM) 30-yr normal (19611990). $0.5^{\circ} \times 0.5^{\circ}$ grids. Monthly

Tmax, Tmin, solar radiation \& precipitation (extrapolated from observed data:

[73])
Greenhouse Gas Cycle
Model and Climate

Change Model (AIM/

climate).$$
\text { climate. }
$$

Upwelling-Diffusion Climate Model (MAGICC).

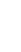

Upwelling-Diffusion Climate Model (IMAGE 1.0/

STAGGER).
1990-2100. Global change in Tmean at 5-yr intervals

until 2030 and then at

2050, 2075 and 2100.

GCM resolution data interpolated to $0.5^{\circ} \times 0.5^{\circ}$

grids. Monthly, regionalized temperature and precipitation changes.

$1990-2100$ at 5 -yr intervals. $0.05^{\circ} \times 0.05^{\circ}$ grids. Monthly Tmax, Tmin, solar radiation \& precipitation. Global mean change Tmean and sea level rise at 5 -yr intervals.

$1990-2100$ at 5 -yr intervals. $0.5^{\circ} \times 1.0^{\circ}$ grids; Mean Monthly and Seasonal Tmax, Tmin \& precipitation. Global mean change Tmean and sea level rise at 5-yr intervals.

Upwelling-Diffusion Climate Model (MAGICC).

Global mean change

Tmean and sea level rise. $0.5^{\circ} \times 0.5^{\circ}$ grids. Monthly, regionalized temperature and precipitation changes, and daily temperatures (the latter are used in the terrestrial vegetation and carbon modules).
Calculation of $\Delta \mathrm{C}$ using different

$2 \times \mathrm{CO}_{2}$ sensitivities.

Use of different

AOGCM $\Delta \mathrm{C}$

patterns including

GISS, GFDL,

$\mathrm{HadCM} 2, \mathrm{CCC}$

\& ECHAM2. Use

of different socio-

economic scenarios.

Calculation of $\Delta \mathrm{C}$

using different

$2 \times \mathrm{CO}_{2}$ sensitivities.

Use of different

GCM $\Delta \mathrm{C}$ patterns -

CSIRO4 and

GFDLQ. Use of

different socio-

economic scenarios.

Calculation of $\Delta \mathrm{C}$

using different

$2 \times \mathrm{CO}_{2}$ sensitivities.

Use of different

socio-economic

scenarios. Regional

patterns of climate

change estimated

using GFDL, GISS,

Oregon State

University, Lawrence

Livermore Nat. Lab.,

UKMO \& MPI

GCMs.

Calculation of $\Delta \mathrm{C}$ using different

$2 \times \mathrm{CO}_{2}$ sensitivities.

Use of different $\Delta \mathrm{C}$

patterns: ECHAM4,

CGCM1, GFDL-

LR15-a, HadCM2

and CSIRO-MK2

GCMs. Use of

different socio-

economic scenarios.

Sensitivity analysis

of changes to various

IAM parameters. 


\begin{tabular}{|c|c|c|c|c|c|c|}
\hline Model & $\begin{array}{l}\text { Geographical } \\
\text { Focus of IAM }\end{array}$ & No. of Emissions Regions ${ }^{\mathrm{a}}$ & $\begin{array}{c}\text { Baseline } \\
\text { Climatology/ } \\
\text { Reference Data }\end{array}$ & $\begin{array}{l}\text { Simple Climate Model } \\
\text { (SCM) Description }\end{array}$ & $\begin{array}{l}\text { Description of internally } \\
\text { calculated climate change } \\
(\Delta \mathrm{C}) \text { variables }\end{array}$ & $\begin{array}{l}\text { Treatment of } \\
\text { uncertainty }\end{array}$ \\
\hline MIT IGSM & $\begin{array}{l}\text { Global and } \\
12 \text { regions }\end{array}$ & $\begin{array}{l}12 \text { - USA, Japan, European } \\
\text { Community, Other OECD, } \\
\text { Central and Eastern Europe, } \\
\text { Former Soviet Union, Energy- } \\
\text { exporting LCDs, China, India, } \\
\text { Dynamic Asian Economies, } \\
\text { Brazil, Rest of World }\end{array}$ & $\begin{array}{l}\text { Climate model initialised } \\
\text { with greenhouse gas } \\
\text { concentrations of year } \\
\text { specified by user. Observed } \\
\text { climate used in Terrestrial } \\
\text { Ecosystem Model (TEM) } \\
\text { and Natural Emissions } \\
\text { Models (NEM). }\end{array}$ & $\begin{array}{l}\text { The Intermediate Complexity } \\
\text { Model (ICM) is a } \\
\text { simplified 2D atmosphere } \\
\text { 3D ocean model coupled } \\
\text { with atmospheric chemistry, } \\
\text { run at } 20 \text { minute time steps } \\
\text { integrated to monthly } \\
\text { resolution. Climate } \\
\text { variables include } \\
\text { temperature, cloudiness, } \\
\text { humidity, precipitation, } \\
\text { and sea level. }\end{array}$ & $\begin{array}{l}\text { Monthly average zonal climate } \\
\text { values over land at } 7.826^{\circ} \\
\text { latitudinal resolution. Used } \\
\text { to perturb observed climate } \\
\text { to produce future climate in } \\
\text { e.g., TEM or NEM. Climate } \\
\text { variables include temperature, } \\
\text { cloudiness, humidity, precipitation, } \\
\text { greenhouse gas and air pollution } \\
\text { levels, sea level. Data interpolated } \\
\text { to varying resolutions dependent } \\
\text { on model being input to e.g., TEM } \\
0.5^{\circ} \times 0.5^{\circ} \text { or NEM } 2.5^{\circ} \times 2.5^{\circ} \text { and } \\
1^{\circ} \times 1^{\circ} \text {. }\end{array}$ & $\begin{array}{l}\text { Sensitivity analysis } \\
\text { of changes to } \\
\text { various IAM } \\
\text { parameters. }\end{array}$ \\
\hline \multicolumn{7}{|c|}{ Tolerable windows approach } \\
\hline ICLIPS & $\begin{array}{l}\text { Global and } \\
11 \text { regions }\end{array}$ & $\begin{array}{l}11 \text { - Sub-Saharan Africa, Centrally } \\
\text { Planned Asia (mainly China), } \\
\text { Former Soviet Union, Middle East/ } \\
\text { North Africa, North America, South } \\
\text { Asia (mainly India), Western Europe, } \\
\text { Eastern Europe, Latin America and } \\
\text { the Caribbean, Pacific OECD (Australia, } \\
\text { New Zealand, Japan), Other Pacific Asia. }\end{array}$ & $\begin{array}{l}\text { 30-yr normal }(1961-90) \text {. } \\
0.5^{\circ} \times 0.5^{\circ} \text { grids. Monthly } \\
\text { Tmax, Tmin, solar } \\
\text { radiation \& precipitation } \\
\text { (extrapolated from } \\
\text { observed data: [73]), } \\
\text { i.e., same as IMAGE2.2. }\end{array}$ & $\begin{array}{l}\text { Energy-balance model. } \\
\text { Modules for non- } \mathrm{CO}_{2} \\
\text { GHGs based on MAGICC. } \\
\text { Climate indicators e.g., } \\
\text { global Tmean, precipitation, } \\
\text { cloud cover and sea level } \\
\text { rise can be combined with } \\
\text { static climate change patterns } \\
\text { derived from GCMs in order } \\
\text { to obtain an approximation of } \\
\text { regional change in climate } \\
\text { attributes. }\end{array}$ & $\begin{array}{l}1990-2200 \text { at } 5 \text {-yr intervals. Global } \\
\text { Tmean, precipitation, cloud cover } \\
\text { and sea level rise. }\end{array}$ & $\begin{array}{l}\text { Use of different } \\
\text { socio-economic } \\
\text { scenarios e.g., SRES } \\
\text { A1, A2, B1, B2. Use } \\
\text { of different AOGCM } \\
\Delta \text { C patterns - } \\
\text { ECHAM3GGa1 } \\
\text { (ECHAM4/OPYC3 } \\
\text { at T42 resolution) } \\
\text { and HadCM2GGaX } \\
\text { ensemble mean } \\
(\text { HadCM2 } \\
2.5^{\circ} \times 3.75^{\circ} \text { ). }\end{array}$ \\
\hline
\end{tabular}

Note. ${ }^{\text {a }}$ This refers to the number of regions explicitly mentioned within emissions scenarios in the SCM. It should be noted that in many cases regional variations can still be calculated exogenously and aggregated to form a global total before input to the SCM. However, this method is less suited to the analysis of different emissions pathways and the evaluation of different environmental policies.

${ }^{\mathrm{b}}$ Unless otherwise stated, future climate data for any individual meteorological variable is calculated by scaling standardised 1 or 2-dimensional future climate change fields from a predefined GCM with the output from the SCM acting as a scaling coefficient. This change field is then added, in the case of temperature, or applied as a percentage change, in the case of precipitation, to the observed baseline. For more information see [178]. 


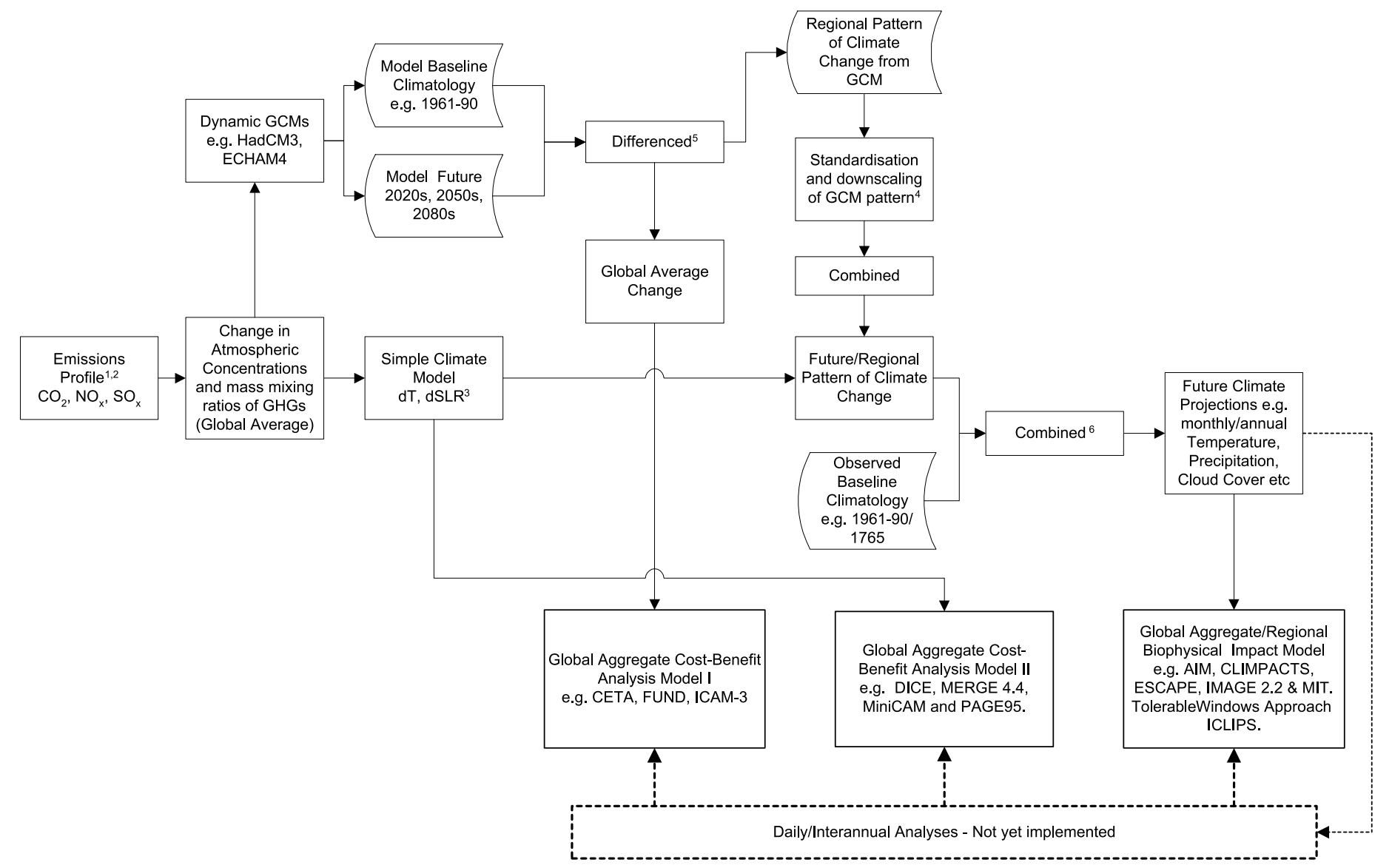

1. From a scenario e.g. IS92a or SRES or arbitary increase/reduction in one or more GHGs.

Can be global or region specific depending on climate model requirements.

ind $1961-90$ but can be pre-industrial e.g. 1765 and as a global average.

Climate change pattern is taken from the end of a climate model experiment where climate signal to noise ratio is maximised. The pattern is then normalised to give regional changes in desired

5. The difference is achieved by subtracting the model baseline climate from the modelled future climate: FutureClimate $\mathrm{m}_{\mathrm{m}}$ - BaselineClimate $_{\mathrm{m}}=$ ClimateChange $_{\mathrm{m}}$ (can be global average on grid cell (Regional Future climate variables derived by adding scaled climate to baseline climate.

Fig. 1. Approaches to the representation of climate change in IAMs. 
Equation (3) shows how a standardised pattern of regional climate change is expressed as a response per ${ }^{\circ} \mathrm{C}$ increase in global temperature. Equation (4) shows how the pattern is then combined with SCM output to generate a future climate at a particular point in time.

Pattern-scaling allows a much wider range of forcing scenarios and climate sensitivities to be considered than is possible from the limited number of GCM simulations which have been performed using a limited range of emissions scenarios. Thus it provides a way of addressing uncertainties due to inter-scenario and inter-model variability. Recent investigations of this technique indicate that it is a legitimate approach, certainly so far as mean climate is concerned $[56,58,59]$. However, disadvantages include the underlying assumptions that the spatial pattern of change remains constant over time and linearly related to globalmean temperature change $[62,63]$ and that the climate response to all greenhouse gases is identical [57,61], and the applicability of this method to regional climate model output, to statistical downscaling and to weather extremes has not been investigated (see Section 3.3).

IAMs have traditionally been divided into two generic categories based on their application to policy issues [39] and which are also reflected in their representation of climate. The first category (see Cost-Benefit Analysis models in Table 3) includes models developed to carry out 'policy optimisation' analyses which explore the economic costs and benefits of implementing controls on greenhouse gas emissions and policies such as the carbon tax [64]. The second category (see Biophysical-impacts models in Table 3 ) includes models developed to carry out 'policy evaluation' exercises, e.g., to look at physical changes in the ecosystem and land-use changes in response to the introduction of regional or global climate change policies such as the Kyoto Protocol. The representation of climate in these two categories is reviewed in Sections 2.3 and 2.4 respectively. More recently, a third category has been developed in which methods such as the Tolerable Windows Approach (see Section 2.5) and Safe Landing Analysis have been applied. The representation of climate in this category of IAMs is based on the same approach as used in Biophysical-impacts models and is reviewed in Section 2.5. IAMs can also be categorised as to whether or not they can be used to analyse adaptation strategies (see Table 3), as discussed in Section 2.6.

Within these four main categories, IAMs can also be classified according to their spatial characteristics, i.e., global, regional and grid box (Table 3). Care is needed, however, in identifying the effective spatial scale of climate information. The baseline climatologies used in many Biophysical-impacts models, for example, have a spatial resolution of $0.5^{\circ}$ by $0.5^{\circ}$, while the GCM-derived perturbations have a much coarser resolution, $2.5^{\circ}$ latitude by $3.75^{\circ}$ longitude in the case of HadCM2 (Table 2). Simply interpolating the GCM output to the higher resolution of the baseline climatology cannot add any physically-based information about sub-grid scale processes. Thus the effective spatial scale of climate change information is limited by the GCM resolution.

\subsection{Cost-Benefit Analysis IAMs for Policy Optimisation}

IAMs such as CETA, DICE, FUND, ICAM-3, MERGE and MiniCAM are primarily concerned with quantifying the economic costs and benefits associated with climate change,

Table 3. Categorisation $(\boldsymbol{})$ of the 13 IAMs reviewed in the paper.? means status is not clear from the published literature.

\begin{tabular}{|c|c|c|c|c|c|c|}
\hline & \multicolumn{3}{|c|}{ Spatial coverage } & \multicolumn{3}{|c|}{ Used to analyse adaptation strategies } \\
\hline & Global & Regional & Grid box & Global & Regional & Grid box \\
\hline \multicolumn{7}{|c|}{ Cost-benefit analysis } \\
\hline CETA & $\boldsymbol{V}$ & & & $?$ & & \\
\hline DICE & $\checkmark$ & & & & & \\
\hline FUND & $\checkmark$ & $\boldsymbol{V}$ & & $\checkmark$ & $\checkmark$ & \\
\hline ICAM-3 & $\boldsymbol{V}$ & $\checkmark$ & & & $\checkmark$ & \\
\hline MERGE 4.4 & $\boldsymbol{\nu}$ & $\checkmark$ & & & & \\
\hline MiniCAM & $\checkmark$ & $\checkmark$ & & & & \\
\hline PAGE95 & $\boldsymbol{V}$ & $\boldsymbol{\nu}$ & & $\boldsymbol{V}$ & & \\
\hline \multicolumn{7}{|c|}{ Biophysical-impacts } \\
\hline AIM & $\boldsymbol{\nu}$ & $\boldsymbol{\nu}$ & $\boldsymbol{\nu}$ & $\boldsymbol{\nu}$ & $\boldsymbol{\nu}$ & ? \\
\hline CLIMPACTS & & $\checkmark$ & $\checkmark$ & & & \\
\hline ESCAPE & & $\checkmark$ & $\checkmark$ & & $\checkmark$ & $\boldsymbol{\nu}$ \\
\hline IMAGE 2.2 & $\boldsymbol{V}$ & $\checkmark$ & $\checkmark$ & $\boldsymbol{V}$ & $\checkmark$ & $?$ \\
\hline MIT & $\boldsymbol{V}$ & $\checkmark$ & $\checkmark$ & & & \\
\hline \multicolumn{7}{|c|}{ Tolerable windows approach } \\
\hline ICLIPS & $\checkmark$ & $\checkmark$ & $\checkmark$ & $\checkmark$ & $\checkmark$ & $\checkmark$ \\
\hline
\end{tabular}


i.e., with the cost of environmental degradation versus the cost of adaptation and mitigation strategies, in order to evaluate possible policy options (see the cost-benefit analysis models in Fig. 1 and Tables 1 and 2). These IAMs generally consist of economic, climate and damage modules [65]. They deal with measures of time-dependent global climate change and provide a global assessment of damage, usually as a function of the change in global-mean temperature. Thus observed baseline or two-dimensional gridded climate data sets are not explicitly referenced or manipulated in such IAMs (but may be implicitly included in construction of the damage functions). The global climate change estimates are derived from predefined emissions scenarios (such as the IPCC's IS92 and SRES scenarios, or those of the Energy Modelling Forum [5]) or from scenarios created by the IAM. Some of these models, such as FUND, use the global temperature change defined by GCMs, while others, such as DICE, MERGE and MiniCAM, use output from SCMs such as global temperature and sea level change.

One of the key features and strengths of such models is their ability to incorporate some stakeholder perceptions of climate change, i.e., those based on monetary proxies such as 'willingness-to-pay' for mitigation strategies. Perceptions which cannot be treated in monetary terms cannot, however, be incorporated. The form of damage functions used in IAMs is well documented in the literature [3-5, 64, 66, 67]. MERGE [67], for example, categorises damage as 'market' (easily quantified economically, e.g., damages to agriculture, forestry and property) and 'non-market' (e.g., damages to biodiversity, human well being and environmental quality). Market damages are assumed to be a quadratic function of temperature change, while non-market damages are modelled using an S-shaped function of regional income and are based on the willingness-to-pay of each of the nine world regions in order to avoid a specified change in temperature.

The other strength of these models is their low computational demand. This means that they can be run on a PC in a matter of hours, and are thus able to provide many estimates of the global and regional burden of climate change, allowing the rapid appraisal of various policy options such as the Kyoto Protocol [5]. However, their use of zero-dimensional (i.e., global) climate data highlights two major weaknesses. First, there is the assumption that the regional weightings based on the pattern of climate change, applied when assimilating the global mean changes into region-specific damage functions, will remain constant through time. For example, Tol [68] assumes that for the OECD-America and OECD-Pacific regions, the monetised loss of species (estimated at US $\$ 0.3$ billion and US $\$ 0.2$ billion per year for a temperature increase of $0.04{ }^{\circ} \mathrm{C}$ per annum, respectively) will remain constant with time. Second, the lack of any dynamic climate simulation model means that feedback mechanisms in the climate system cannot be incorporated.

\subsection{Biophysical-Impact Based IAMs for Policy Evaluation}

Biophysical-impact based IAMs (see Fig. 1 and Tables 1 and 2) simulate quantitative and regionally explicit biophysical impacts rather than focusing on policy optimisation and economic damages [65]. They tend to have a regional focus, but some can be aggregated to the global level e.g., AIM, CLIMPACTS, ESCAPE, IMAGE and MIT IGSM [8]. Of this group of models, IMAGE 2.2 is probably the most sophisticated. Even those without the ability to aggregate to the global level, such as CLIMPACTS, retain a global element, normally concerning (i) the conversion of regional greenhouse gas emissions to global climate change, and (ii) economic development and population growth. The majority of these models determine future climates relative to 30-year baseline climatologies (typically 1961-1990). However, the global part of such IAMs tends to be relatively simple. As Table 2 indicates, this sort of model (like some of the globally-aggregated economic models) uses an upwellingdiffusion model, such as MAGICC [51], to calculate global changes in temperature. These are combined with patternscaling (e.g., SCENGEN [57]) to produce regional timedependent climate change scenarios.

The MIT IGSM model also uses a reference baseline climate from which to create future climates but, unlike other Biophysical-impact based models, obtains spatiallyresolved scenarios from an Intermediate Complexity Model (ICM) rather than from the combination of SCM and GCM described above. The ICM consists of a coupled atmospheric chemistry/2D-climate model and a 3D-ocean model. It has 24 latitude grid points $\left(7.826^{\circ}\right.$ resolution) and nine vertical levels, whilst the ocean model is a simplified version of the GISS Ocean Circulation Model. The coupled model is run at 20-minute intervals but output is aggregated to monthly averages. Comparisons with GCM output indicate that the ICM is capable of replicating present-day climate, together with the climate change patterns produced by GCMs using different emissions scenarios. Emissions are output from the Emissions Prediction and Policy Analysis (EPPA) model and input into the ICM. Output from the latter model is interpolated and used to adjust the observed climatology employed, for example, in the Terrestrial-Ecosystem Model at a $0.5^{\circ} \times 0.5^{\circ}$ resolution, which estimates the terrestrial carbon flux, and the Natural Emissions Models at a $1^{\circ} \times 1^{\circ}$ resolution.

A potential advantage of the Biophysical-impact based IAMs is that they are able to produce estimates of the regional impacts of climate change at a relatively high spatial resolution. Thus they are able to provide information about regional variations in potential impacts and highlight sub-national scale vulnerabilities, while also assimilating the influence of global climate change forcing from outside the immediate region(s) of interest. However, the reliability of such high-resolution information should be carefully 
assessed by users, and the effective scale of the climate change information identified (see Section 2.2).

Biophysical-impacts based IAMs also have a number of shortcomings, which partly stem from their relatively poorly defined economic modules. For example, stakeholder perceptions cannot be included. In addition, it is not generally possible to incorporate large-scale feedbacks due to a mismatch in spatial coverage. For example, while it is possible to simulate a decrease in biological diversity at the regional level (for example, New Zealand in the case of CLIMPACTS), the global increase in carbon release through enhanced soil respiration is not calculated and does not, therefore, enhance global anthropogenic climate change (a feedback quantified by Cox et al. [69] and White et al. [70]). Thus, although these models incorporate global climate change, the regional impacts, such as additional carbon emissions, are not transferred back to the global scale.

Biophysical-impact based IAMs are, however, able to incorporate some feedback mechanisms. The IMAGE model [71], for example, incorporates not only population growth and energy/emission modules but also dynamic ecosystem and climate modules, which allow the incorporation of some complex feedback mechanisms, such as carbon cycleecosystem die-back due to climate change, which leads to increased levels of $\mathrm{CO}_{2}$ in the atmosphere, which in turn leads to an accelerated rate of climate change [72]. IMAGE provides an insight into changes in land cover over time due to climatic, demographic and economic factors and links these explicitly with $\mathrm{CO}_{2}$ and other greenhouse gas fluxes [39].

The IMAGE model has a global coverage, dividing the world into 19 political entities (see Table 2), 17 of which have their own emissions information which can be specified in the climate module. The other two regions are Antarctica and Greenland, neither of which contribute significantly in terms of emissions. The climate module itself is an upwelling-diffusion model, based on MAGICC [51], which provides global changes in mean temperature and precipitation. This is combined with a pattern-scaling routine, which takes into account the role of sulphate aerosols in the atmosphere, to generate two-dimensional, time-dependent climate change futures. The standardised patterns used for scaling come from several coupled atmosphere-ocean GCMs. The default pattern, for example, is constructed using HadCM2 output. MAGICC is driven by standard emissions scenarios such as those published in the IPCC SRES, however, carbon emissions at the regional level can be modified within IMAGE by the user if required.

While socio-economic input data (such as emissions, gross domestic product and population growth) and impact analyses are reported for 17 world regions in IMAGE, the climate data (observed and future projections) used in the agricultural and dynamic vegetation modules are handled at the gridbox level. The size of the gridbox is determined by the resolution of the observed baseline climatology: currently $0.5^{\circ} \times 0.5^{\circ}[73]$.
An IAM with the complexity of IMAGE has a number of advantages. The first is its diverse applications. It can be used to assess the potential economic costs and benefits of mitigation and adaptation policies [74] and can also be used to quantify the potential impacts of climate change on various exposure units, such as the risk to human health from the spread of disease, the loss of natural habitats, and changes in yields of the world's major crops. However, it still relies on the use of an SCM and pattern-scaling techniques to produce climate scenarios. Furthermore, whilst it is able to calculate climate and the resulting impacts at the individual gridbox level, the spatial scale is still relatively coarse (i.e., $0.5^{\circ} \times 0.5^{\circ}$ for the baseline climatology and, typically, $2.5^{\circ}$ by $3.75^{\circ}$ for the climate change information). Gridboxes are categorised by the dominant characteristics of the box which means that broad generalisations regarding factors such as land cover and soil type are made and no account is taken of variability within a box. In addition, while mean daily meteorological data are used in the terrestrial vegetation and carbon modules of IMAGE, there is no way of assessing the impacts resulting from changes in variability (on interannual and decadal timescales, for example). Future monthly mean daily temperatures are derived from an observed monthly mean daily temperature series to which the monthly mean temperature increase is simply added every five years. Thus changes in the frequency of extreme weather events can only occur due to changes in mean climate and not due to changes in variability.

\subsection{Policy Guidance IAMs}

ICLIPS represents this third group of models and incorporates elements of both policy-optimisation and policyevaluation frameworks whilst also enabling stakeholder perception, in the form of willingness-to-pay, to be included in the analysis [75-77]. It starts with the explicit specification of "guardrails," i.e., climate impacts, mitigation costs and burden sharing schemes that are perceived as intolerable by stakeholders. Its aims are to identify critical thresholds of climate change by exploring an extended range of changes in climate and $\mathrm{CO}_{2}$ concentrations and to determine emission paths that are compatible with the predefined guardrails. It produces regionalised impacts projections specified in biophysical units (such as the percentage of protected areas (e.g., nature reserves) that are in danger of becoming unviable). Climate impact response functions are developed which incorporate elements from both policy evaluation and optimisation models, such as the regional specificity of policy evaluation models and the damage functions used in policy optimisation models [78, 79]. Extensions of the ICLIPS model have been used to explore the conditions under which a major change in the thermohaline circulation could occur [44].

At the core of ICLIPS is the Tolerable Windows Approach (TWA). This works by allowing policymakers 
and other social actors to specify their willingness to accept and pay for a certain amount of climate change in their region. These decisions are made with the assistance of climate impact response functions [80]. Tolerable climate windows are then produced which incorporate the acceptable level of climate change previously identified, for example, temperature change, precipitation change and sea level rise. Climate constraints are then input to a greenhouse gas emissions-climate model to produce sets of emissions paths that keep the climate within the tolerable climate window.

\subsection{IAMs and Adaptation}

As well as being used to assess impacts and mitigation strategies, IAMs can also be used to analyse adaptation strategies. Out of the thirteen IAMs reviewed here, seven (AIM, ESCAPE, FUND, ICAM-3, ICLIPS, IMAGE and PAGE95) incorporate some element of adaptation (Table 3). Of these, three deal with adaptation exogenously (ESCAPE, ICLIPS and FUND). In all seven models, adaptation is only very crudely incorporated: impacts are only identified when increases in temperature exceed a time-variant tolerance level.

In the case of PAGE95, for example, the tolerance level can be raised by the implementation of, or investment in, adaptive policies, meaning that the magnitude and rate of climate change required to impact on an exposure unit are increased. Such policies include the building of sea walls and the development of drought resistant crops. AIM uses global and regional climatic impacts generated by the AIM/impact module to assess the effectiveness of adaptation strategies in terms of their modification of the direct impacts. AIM can, for example, assess the costs and benefits associated with the implementation of policy measures such as short-term mitigation strategies and long-term adaptation policies (for example, increased use of renewable energy and energy-saving technologies and reforestation) [81]. ESCAPE feeds adaptive strategies into the climate and sea level change to impacts' module. The strategies include, for example, the adaptation of wheat crops to temperature change through genetic modification by raising the threshold temperature for damage.

The adaptive measures mentioned above are all implemented at the governmental or institutional level. IAMs do not currently take into account local adaptive strategies, nor do they simulate the role of extreme weather events in stimulating adaptive behaviour.

\subsection{IAMs and Uncertainties}

The processes represented in all IAM modules are subject to uncertainties due to errors or unknown quantities, for example, errors in data collection, gaps in knowledge and the inability to model complex processes sufficiently accurately [65]. The treatment of uncertainty varies from
IAM to IAM, based on the structure and form of the individual model - there is no standard method. However, the main methods for dealing with uncertainty include:

(1) using a set of future emissions scenarios which are selected to span a subjectively-determined range of representative futures and also by using different climate sensitivities (thus addressing inter-scenario and intermodel variability in climate scenarios, see Section 1);

(2) sensitivity analysis to examine the sensitivity of outputs to changes in key parameters or models or policies (selected subjectively); and,

(3) specifying probability distributions for many inputs and running the models many times, sampling over the input values in some efficient way. This enables the investigator to determine both how uncertain an input value is, and how sensitive an output value is to that uncertainty.

Biophysical-impact models such as AIM, CLIMPACTS, ESCAPE and IMAGE, together with the ICLIPS model, take some account of uncertainty by using different climate sensitivities, different GCM climate change patterns and different socio-economic scenarios. AIM uses several GCMs including GISS, GFDL, HadCM2 and CCC [82]. CLIMPACTS uses only two, drawn from a set of six GCMs found to accurately replicate observed climate over the Australian-New Zealand region. The two selected models are CISIRO4 and GFDLQ, both of which have been shown to have superior performance over the region of interest [83]. ESCAPE also uses output from a range of GCMs and examines climate change impacts for different climate sensitivities. However, uncertainties are not passed on to other modules. IMAGE 2.2 evaluates uncertainty due to climate sensitivity by simulating global temperature changes for $2.5^{\circ} \mathrm{C}$ (median IPCC sensitivity value), $1.5^{\circ} \mathrm{C}$ (low sensitivity) and $4.5^{\circ} \mathrm{C}$ (high sensitivity). Uncertainty in regional climate change patterns is evaluated by using several different GCMs (i.e., ECHAM4, CGCM1, GFDLLR15-a, HadCM2 and CSIRO-MK2). ICLIPS takes account of different climate sensitivities and uses a number of different emissions scenarios and GCMs [78, 79].

The MIT IGSM carries out a series of runs, varying key parameters and assumptions by finite amounts from their initial values. On the climate side, variations can be made in the EPPA and the coupled 2D chemistry/climate models. The climate model has recently been used to derive a joint probability distribution function of three uncertain properties of the climate system: (i) climate sensitivity; (ii) rate of heat uptake by the ocean; and, (iii) strength of anthropogenic aerosol forcing [84]. For climate sensitivity, for example, the 5 to $95 \%$ confidence intervals are estimated to be 1.4 to $7.7^{\circ} \mathrm{K}[84]$.

PAGE95 and FUND use probability distributions to explore uncertainty. PAGE95 [3, 85], for example, uses a triangular probability distribution to represent uncertainty in each input parameter. Between 50 and 108 "uncertain" 
parameters are used, depending on the regions and impact sectors being investigated. For a full assessment, PAGE95 carries out 250 calculations for variables representing global warming over time, damages, adaptive costs and preventative costs. Latin hypercube sampling [86-88] is used to select a different set of values for the "uncertain" input parameters in each of the 250 calculations in order to build up an approximate probability distribution. Tol $[5,68]$ quantifies the uncertainties in FUND based on expert knowledge, i.e., from qualitative interpretation of the appropriate literature and discussions with relevant experts. He has identified appropriate distribution types for different sensitivities, for example, climate sensitivity is based on a gamma distribution, as is sea level sensitivity, whilst hurricane and storm sensitivity are based on a normal distribution and the atmospheric lifetime of methane is based on a triangular distribution. In the case of FUND, the best guesses are equal to the modal values of the distribution (the most likely value). The advantages of this method include a better estimate of mean outputs, a probability distribution of outputs can be produced and the relative importance of inputs identified.

The FUND model is unusual in that it not only calculates annual change in global mean temperature, but also incorporates some climate extremes such as sea level rise, hurricane activity, winter precipitation and winter storm activity $[5,64,68]$. However, the frequency and intensity of these events are determined solely as a linear function of global mean temperature (details of how this is done are not given in the published literature).

None of the current IAMs take into account the influence of natural climate variability, including interannual and decadal variability. Only two of the IAMs listed in Table 2 (DICE and FUND) use time-series data for their baseline climatology although, in both cases, only annual averages are used. All the other IAMs use annual, seasonal or monthly long-term averages (typically 30-year normals). Wider use of time-series data would allow some representation of natural climate variability. The use of ensembles from the GCM experiments used to derive climate change patterns would also be of benefit, because intra-ensemble variability is a direct reflection of natural climate variability (Section 1).

Thus the inability of IAMs to incorporate extreme weather events remains a major weakness, although opportunities for representing scenarios of extremes are beginning to emerge, as discussed in the next section.

\section{EVALUATION OF SCENARIO DEVELOPMENT METHODS FOR WEATHER EXTREMES AND THEIR POTENTIAL FOR USE IN IAMs}

\subsection{Recent Work on Scenario Development Methods for Extremes}

Relatively few studies have focused specifically on the construction of scenarios of extremes rather than mean climate, in part, because of the problems associated with the reliability and availability of high spatial and temporal resolution climate model output $[89,90]$. Initial studies, particularly of precipitation, have tended to focus more on changes in interannual variability [23,91-93] or changes in distributions rather than specific extreme events. Gregory and Mitchell [94], for example, examined changes in the parameters characterising daily temperature and precipitation simulated by the Hadley Centre UKHI GCM, while Hennessy et al. [95] investigated changes in precipitation frequency distributions and in the relative contributions of convective and non-convective precipitation mechanisms in the UKHI and CSIRO9 GCMs. Wetherald and Manabe [96] focused on changes in soil moisture (particularly as an indicator of summer dryness) simulated in four GFDL GCM experiments.

With the greater availability of daily output from GCMs, this output has begun to be used directly to construct scenarios of specific extremes. A number of these studies are summarised in Table 4, focusing on temperature and precipitation extremes. Some of them use time slices which are relatively short for the analysis of extremes ( 10 or 20 years) and some are based on equilibrium rather than the newer generation of transient, coupled atmosphere-ocean GCMs.

Most recently, a few studies have used output from regional climate models (RCMs) to construct scenarios of extremes [97-102]. Durman et al. [100], for example, focus on the occurrence of intense precipitation events over Europe and the UK defined using two different thresholds ( $15 \mathrm{~mm}$ per day and the upper $1 \%$ percentile calculated from the model control run). A comparison is made of future scenarios (for 2080 2100) constructed from Hadley Centre HadCM2 GCM and RCM output in order to determine the added value of using high-resolution model output [100]. Jones and Reid [101] also use the HadCM2 RCM to construct future scenarios of extreme precipitation for the UK, in this case focusing on the occurrence of the top 10\% quantile events (calculated using the method of Osborn et al. [103]) and 5, 10, 20 and 50 year return period events. This RCM was also used by Booij [102] to construct scenarios of return period precipitation events for the Meuse catchment in western Europe and to compare these with HIRHAM4 RCM and three GCM-based scenarios. The most recent generation of the Hadley Centre RCM, HadRM3, was used to construct the UKCIP02 scenarios for the UK [60] which provide some information about changes in extreme events (e.g., "intense" precipitation days and "extremely" warm days).

RCMs allow the dynamical downscaling of GCM output to the higher spatial resolutions which are more appropriate for the construction of scenarios of extremes. Statistical downscaling provides a less computer-intensive method of downscaling [104-106], but has not been widely used to investigate changes in extremes. Wagner [107] used a probability model based on thresholds to show that changes in temperature extremes are more sensitive to changes in 
Table 4. Summary of recent studies which use GCM output directly to construct scenarios of temperature and precipitation extremes.

\begin{tabular}{|c|c|c|c|}
\hline Study & Extremes & Region & GCM \\
\hline Booij [102] & $\begin{array}{l}\text { Precipitation: } 10,20, \\
\quad 50,100 \text { year return periods }\end{array}$ & $\begin{array}{l}\text { Meuse, western } \\
\text { Europe }\end{array}$ & $\begin{array}{l}\text { CGCM1, HadCM3, } \\
\text { CSIRO9 } \\
\text { 20/30 year time slices }\end{array}$ \\
\hline Dai et al. [188] & $\begin{array}{l}\text { Frequency and persistence } \\
\text { of 'hot' days ( }>80 \text { th percentile) } \\
\text { Storm activity }\end{array}$ & Global, USA & $\begin{array}{l}\text { NCAR CSM } \\
\text { Coupled model } \\
2 \text { scenarios } \\
20 \text { year time slices }\end{array}$ \\
\hline Delworth et al. [189] & $\begin{array}{l}\text { Steadman heat index (based on } \\
\text { monthly temperature and } \\
\text { atmospheric moisture) }\end{array}$ & Global & $\begin{array}{l}\text { GFDL } \\
\text { Coupled model } \\
20 \text { simulations } \\
30 \text { year time slices }\end{array}$ \\
\hline Huth et al. [190] & Heat waves/dry spells & Czech Republic & $\begin{array}{l}\text { ECHAM3 } \\
\text { Equilibrium model } \\
30 \text { year time slices }\end{array}$ \\
\hline Kharin and Zwiers [89] & $\begin{array}{l}\text { Temperature, precipitation, } \\
\text { wind: } 20 \text { year return periods, } \\
\text { thresholds, cooling \& heating } \\
\text { degree days }\end{array}$ & Global, Canada & $\begin{array}{l}\text { CGCM1 } \\
\text { Coupled model } \\
20 \text { ensembles } \\
21 \text { year time slices }\end{array}$ \\
\hline Kothavala [191] & $\begin{array}{l}\text { Precipitation: return periods, } \\
\text { percentiles and Palmer Drought } \\
\text { Severity Index (PDSI) }\end{array}$ & Midwest USA & $\begin{array}{l}\text { CCM1-OZ } \\
\text { Equilibrium model } \\
10 \text { year time slices }\end{array}$ \\
\hline Kothavala [192] & $\begin{array}{l}\text { PDSI (based on monthly temperature } \\
\text { and precipitation) }\end{array}$ & Eastern Australia & $\begin{array}{l}\text { CCM0 } \\
\text { Coupled model } \\
30 \text { year time slices }\end{array}$ \\
\hline Kyselý [110] & $\begin{array}{l}\text { Temperature }(\max / \min ): 20 \text { and } \\
50 \text { year return periods }\end{array}$ & Central Europe & $\begin{array}{l}\text { ECHAM/CCCM } \\
30 / 20 \text { year time slices }\end{array}$ \\
\hline McGuffie et al. [193] & $\begin{array}{l}\text { Temperature and precipitation: Return } \\
\text { periods and range of descriptive } \\
\text { regional statistics }\end{array}$ & Global, 5 IPCC regions & $\begin{array}{l}20 \text { equilibrium } \\
\text { GCMs } \\
10 \text { year time slices }\end{array}$ \\
\hline Palmer and Räisãnen [157] & Precipitation: 'Very wet' winters/summers & $\begin{array}{l}\text { Europe, Asian } \\
\text { monsoon region }\end{array}$ & $\begin{array}{l}19 \text { coupled GCMs } \\
\text { used in TAR } \\
30 \text { year time slices }\end{array}$ \\
\hline Yonetani and Gordon [194] & $\begin{array}{l}\text { Temperature, precipitation: } \mathrm{max} / \mathrm{min} \\
1 \times \mathrm{CO}_{2} \text { seasonal/annual values }\end{array}$ & Global & $\begin{array}{l}\text { CSIRO } \\
\text { Coupled model } \\
1 \times \mathrm{CO}_{2} / 2 \times \mathrm{CO}_{2} \\
100 / 30 \text { year time } \\
\text { slices }\end{array}$ \\
\hline Zwiers and Kharin [113] & $\begin{array}{l}\text { Temperature, precipitation and wind: } \\
20 \text { year return periods and thresholds }\end{array}$ & Global, Canada & $\begin{array}{l}\text { CCC GCM2 } \\
\text { Equilibrium model } \\
20 \text { year time slices }\end{array}$ \\
\hline
\end{tabular}

variability than mean climate (using output from the ECHAM GCM and daily temperature data for Berlin). A similar conclusion was reached using a first order autoregressive Markov Chain model [108]. Although statistical downscaling has rarely been used specifically to construct scenarios of extremes (exceptions are Brandsma and Buishand [109] with respect to precipitation and Kyselý [110] with respect to temperature), a number of studies do include analyses of relevant indicators, particularly as part of the validation of the methodology (Table 5).

The IPCC TAR gives greater consideration to extreme events than previous assessments and cites many of the references identified above. The most concise summary of observed and projected changes in extreme events is provided by Table 1 from the Working Group 1 Summary for Policymakers. It provides an assessment of confidence in the observed and projected changes based on observational and modelling studies, as well as the physical plausibility of future projections across all commonly-used emissions scenarios, based on expert judgement. Higher maximum temperatures and more hot days over nearly all land areas, together with higher minimum temperatures, fewer cold days and frost days over nearly all land areas, for example, are considered 'very likely' (i.e., 90-99\% chance) during the 21 st century. More intense precipitation events are also projected to be 'very likely' over many areas, while increased summer continental drying and the associated risk of drought are considered 'likely' (i.e., 66-90\% chance) over most mid-latitude continental interiors.

While reflecting the advances that have made in the study of observed and projected changes in extremes since the SAR, the TAR stresses the continuing problems and 
Table 5. Statistical downscaling studies which include analysis of extreme event indicators.

\begin{tabular}{|c|c|}
\hline Indicators studied & Study \\
\hline $\begin{array}{l}\text { Studies which include } \\
\text { analysis of precipitation- } \\
\text { related extreme indicators, } \\
\text { e.g., length of (longest) } \\
\text { wet/dry spells, return } \\
\text { period events, ranked } \\
\text { extremes }\end{array}$ & $\begin{array}{l}\text { Bardossy and Plate [135, 195] } \\
\text { Bates } \text { et al. [196] } \\
\text { Beckman and Buishand [152] } \\
\text { Bogardi } \text { et al. [138] } \\
\text { Brandsma and Buishand [109] } \\
\text { Charles } \text { et al. } \text { [159] } \\
\text { Conway and Jones [129] } \\
\text { Corte-Real } \text { et al. }[143] \\
\text { Goodess [126] } \\
\text { Hay et al. [133, 136] } \\
\text { Hughes } \text { et al. }[197] \\
\text { Semenov } \text { et al. } \text { [198] } \\
\text { Weichert and Burger [199] } \\
\text { Wilby [149] } \\
\text { Wilby et al. [141, 150] } \\
\text { Wilks [200] } \\
\text { Wilson } \text { et al. }[134,137]\end{array}$ \\
\hline $\begin{array}{l}\text { Studies which include } \\
\text { analysis of storm- } \\
\text { related indicators, } \\
\text { e.g., storm length, } \\
\text { inter-storm arrival } \\
\text { time }\end{array}$ & $\begin{array}{l}\text { Hughes et al. [139] } \\
\text { Hughes and Guttorp [140] } \\
\text { Schnur and Lettenmaier [130] }\end{array}$ \\
\hline $\begin{array}{l}\text { Studies which include } \\
\text { analysis of temperature- } \\
\text { related extreme indicators, } \\
\text { e.g., annual maximima/ } \\
\text { minima, heat waves and } \\
\text { cold spells, frosts, } \\
\text { threshold exceedence }\end{array}$ & $\begin{array}{l}\text { Hayhoe [201] } \\
\text { Huth et al. [144] } \\
\text { Kyselý [110] } \\
\text { Palutikof et al. [131] } \\
\text { Schubert [148] } \\
\text { Schubert and Henderson- } \\
\quad \text { Sellers [145] } \\
\text { Trigo and Palutikof [202] } \\
\text { Winkler } \text { et al. } \text { [146] }\end{array}$ \\
\hline
\end{tabular}

uncertainties associated with extreme weather events and recommends further research effort to address these issues.

\subsection{Suitability of Scenario Development Methods}

The IPCC TAR identifies five criteria, adapted from Smith and Hulme [111], for assessing the suitability of each type of climate scenario for use in impact assessment:

1. Consistency at regional level with global projections. Scenario changes in regional climate may lie outside the range of global mean changes but should be consistent with theory and model-based results.

2. Physical plausibility and realism. Changes in climate should be physically plausible, such that changes in different climatic variables are mutually consistent and credible.

3. Appropriateness of information for impact assessments. Scenarios should present climate changes at an appropriate temporal and spatial scale, for a sufficient number of variables, and over an adequate time horizon to allow for impact assessments.

4. Representativeness of the potential range of future regional climate change.

5. Accessibility. The information required for developing climate scenarios should be readily available and easily accessible for use in impact assessments.

These criteria are all applicable to scenarios of extremes and their use in IAMs, with the appropriateness of information, and the associated issues of scale, being of particular concern (see Sections 1 and 4). Extremes place additional demands on climate models and scenario development methods: higher-order statistics (such as standard deviations and skewness), together with the tails of distributions, not just mean values, must be well reproduced. Different extreme events/variables exhibit different characteristics that must be reliably captured by climate-change scenarios, and hence place different demands upon climate models and scenario development methods. For example, the demands arising from the need to reproduce daily precipitation totals which are typically described by a mixed statistical distribution are different to the case of variables with a quasi-Gaussian distribution such as daily temperature. In both cases, extreme events are highly dependent on spatial scale, while multi-month drought occurrence is less so, but instead introduces a need to reproduce the correct persistence levels. Certain sectors also require that realistic inter-site relationships are maintained (e.g., hydrological modelling), while others (e.g., certain crop models [112]) require realistic inter-variable relationships.

While the need to generate scenarios that successfully reproduce present-day climate variability and extremes and that also give reliable and plausible estimates of climate change is paramount, a number of other issues must also be addressed, particularly with respect to integrated assessment. Ideally, scenarios should have estimates of their associated uncertainty (see Sections 1 and 3.5) and should be able to be scaled to reflect a range of possible greenhouse gas emissions pathways. In the following section, the advantages and disadvantages of various methods for the construction of scenarios of extremes are summarised in the light of these additional criteria.

\subsection{Direct Use of Climate Model Output}

An overriding problem - and hence the need for more sophisticated scenario development methods - is that output from GCMs cannot, in general, be used to directly quantify future variability and extremes, particularly at the station or local level, because of bias in simulated means and variability of present-day climate and weather [90, 113]. This bias may originate from systematic model errors [94, 95], from spatial scale incompatibilities (area-mean grid-box output has different statistical properties to station 
data $[114,115])$ and due to the exclusion of sub-gridscale processes.

In the development of scenarios of mean climate change, the bias in simulated means is the main difficulty and can be "overcome" by assuming that the climate change is independent of these mean biases and, therefore, applying climate change fields to appropriate observed baseline climatologies (as is currently done in IAMs, see Section 2.2). A similar approach can be used for the development of scenarios that focus on climate variability and extremes $[116,117]$, i.e., by assuming that changes in higher-order statistical parameters (such as variance, skewness and persistence) are reliable, despite differences between observed and simulated present-day values of these parameters. Additionally, it may be possible to use appropriate statistical manipulation to reproduce the present-day climate characteristics. Alternatively, extremes and their changes can be defined in a relative rather than absolute sense (i.e., percentile or quantile values rather than absolute thresholds) in order to reduce model biases. The advantages and disadvantages of these various approaches are summarised in Table 6. Single examples of the implementation of each approach are given, though it should be noted that the range of choices that could be made when implementing each approach is potentially very broad.

For GCMs to become more reliable in their simulation of variability and extremes as well as means, requires not only an improvement in the models, but also a solution to the two major spatial resolution problems of scale incompatibilities and sub-grid-scale processes. If direct model output is to be used, then these problems can only be overcome by an increase in the spatial resolution of climate models together with improvement in their reliability. Higher-resolution global (such as timeslice [118]) or regional (nested within a global model $[119,120])$ models have begun to address this problem. Time-slice simulations have recently been used to explore changes in intense rainfall and wet/dry day spells [121], but output from RCMs is more widely available than output from timeslice simulations and thus provides a more viable approach. It should not, however, be assumed that the higher resolution of RCMs automatically provides more meaningful or reliable spatial detail $[60,100,122,123]$.

RCM output has been less widely used than GCM output for constructing scenarios of extremes (because the latter is

Table 6. Summary of the advantages and disadvantages of the direct use of General Circulation Model output to construct scenarios of extremes. $\boldsymbol{V}=$ advantage, $\boldsymbol{x}=$ disadvantage, ?= advantage/disadvantage of the method is uncertain.

Advantages/disadvantages of the general approach

$\checkmark \quad$ Provides physically-consistent multi-variate information

$\boldsymbol{X} \quad$ Spatial-scale problems arise, i.e., grid box rather than point values

$\mathbf{x} \quad$ Even area-averaged extremes (i.e., grid-box values) may not be reliably simulated

1. Diagnosed changes in statistical parameters (mean, plus higher-order parameters, such as variance, scale and shape, etc.) applied to observed baseline time series. For example of implementation see [203]

$\checkmark \quad$ Simple method

$\checkmark \quad$ Suitable for scaling

$\boldsymbol{X} \quad$ Non-realistic scenarios, e.g., negative precipitation, may occur when the changes are applied to the baseline climatology

$\boldsymbol{x}$ Assumes biases will be unchanged in the future

2. As 1, but changes are applied to weather generator parameters, previously tuned to reproduce observed climate. For example of implementation see [204]

$\checkmark \quad$ Long and/or multiple time series can be generated for analysis of extremes/uncertainties

$\checkmark \quad$ Suitable for scaling

$\boldsymbol{x} \quad$ Weather generators tend to underestimate variability and persistence, e.g., length of wet/dry spells

$\boldsymbol{X} \quad$ May be difficult to adjust weather generator parameters in a consistent way

3. Direct model time series used, after appropriate statistical manipulation to reproduce present-day climate characteristics. For example of implementation see [205]

$\checkmark \quad$ May overcome some model biases

$\boldsymbol{x} \quad$ May be more difficult to manipulate extremes than mean values

$\boldsymbol{x} \quad$ Assumes model biases will be unchanged in the future

? $\quad$ Either 'un-intelligent' or 'informed' manipulation may be applied, the latter using validation/statistical downscaling approaches to adjust model output for specific physically-identified biases

? $\quad$ Less suitable for scaling

4. Model output used to assess specific extremes (via percentile or extreme value distribution approaches), which are defined in a relative rather than absolute sense. For example of implementation see [100]

$\checkmark \quad$ May avoid some systematic model deficiencies and facilitates model inter-comparisons

$\boldsymbol{\sim} \quad$ May overcome some spatial-scale incompatibilities

$\boldsymbol{X} \quad$ Assumes model biases will be unchanged in the future (because percentiles or thresholds are defined from the model control period)

? $\quad$ Less suitable for scaling

? Stakeholders may find it harder to relate to 'relative' extremes 
Table 7. Summary of the advantages and disadvantages of the direct use of regional climate model output to construct scenarios of extremes. $\boldsymbol{V}=$ advantage, $\boldsymbol{X}=$ disadvantage, $?=$ advantage/disadvantage of the method is uncertain.

Advantages/disadvantages of the general approach. For example of implementation see [97-102]

$\boldsymbol{\sim}$ Provides physically-consistent multi-variate information

$\checkmark \quad$ Higher spatial resolution than GCMs should reduce some biases (e.g., more intense extremes)

$\boldsymbol{x} \quad$ Relatively short (e.g., 30 year) runs make it difficult to assess multi-decadal natural variability

$\boldsymbol{x}$ Runs may not be available for time periods of interest (e.g., 2020s)

$\boldsymbol{x}$ Relatively few simulations/ensembles available

$\boldsymbol{x}$ Affected by biases in the underlying GCM

? Added value of higher spatial resolution needs to be demonstrated

? Scaling may be less robust than from GCMs and for mean climate, in part, because of shorter model simulations

more widely available), however, the advantages and disadvantages of this general approach are outlined in Table 7. RCM output can be used in the same way as GCM output, thus the potential advantages/disadvantages of methods 1 to 4 listed in Table 6 are also applicable to RCM output.

GCMs/RCMs must be run off-line rather than on-line in IAMs because they are so computationally complex and demanding. Their output is currently utilised in IAMs to provide information about changes in mean climate, but this requires pattern-scaling, the advantages and disadvantages of which are discussed in Section 2.2 with respect to mean climate. Additional concerns arise with respect to the scaling of extremes.

The most detailed assessment of pattern-scaling to date is that of Mitchell [59]. His study, like that of Mitchell et al. [56], focused on changes in mean climate rather than extremes. However, a number of its conclusions may be relevant to scaling extremes. The sources of error identified by the study, for example, include non-linear grid-box responses to radiative forcing, which undermine the underlying assumption of linearity. The preferred method is to take the pattern from a regression based on the full model period rather than from a short (e.g., 20 year) period at the end of the simulation because, if the response is non-linear, the magnitudes of any instantaneous errors will be minimised (though they may change sign during the course of the simulation).

The Mitchell study [59] also suggests that it is possible to scale interannual variability (i.e., standard deviations), although the errors (i.e., due to deviations from linearity) are larger than for mean values. If, furthermore, it is assumed that the variable in question has a Gaussian distribution, changes in the entire probability distribution may be estimated by individually scaling the mean and standard deviation. It may also be possible to scale non-Gaussian variables by estimating secondary parameters: for example, it may be possible to estimate precipitation by scaling the mean and standard deviation and estimating from them the shape and scale parameters of the gamma distribution.

The Mitchell study [59] is, however, largely based on a single model (HadCM2), which raises a question as to whether the findings are model dependent. Clearly, the legitimacy of using scaling techniques for extremes, which may change nonlinearly $[10,108]$ needs specific investigation. Is it possible, for example, to capture the non-linearities by using quadratic rather than linear regression or by using a variable other than global temperature as the scalar? Another important question for extremes is whether it is possible to scale daily time series? And, if temperature and precipitation are scaled separately, is the spatial coherence of these variables maintained? Thus there are a number of issues that must be addressed before GCM or RCM output can be used to provide information about extreme weather events in IAMs.

\subsection{Statistical Downscaling}

A range of statistical downscaling methods has been developed in recent years (see the following reviews: [104-106, 124-126]), though these have not been designed specifically for downscaling weather extremes. Relationships between larger-scale climate variables (such as atmospheric circulation) and local surface climate variables (such as daily temperature and precipitation), derived empirically using observed data, can be applied to the generation of climate scenarios, under the two assumptions that the larger-scale climate variables are more reliably simulated by climate models, and that the relationships remain valid under a changed climate. Theoretically, the latter assumption (of stationarity) should be valid if all the necessary predictor variables (such as atmospheric circulation, temperature and humidity [125, 127]) are used and the statistical model is appropriately structured to enable it to represent interactions and non-linearities. In practice, however, this may be limited by the availability of sufficiently long data series to determine the important predictors on all necessary time scales (a problem that is exacerbated if the variables that generate inter-daily to inter-annual variability are different to those that cause climate change). Nevertheless, given adequate data, statistical downscaling has sufficient advantages to warrant consideration as a scenariogeneration method in IAMs. The common advantages and disadvantages of this approach are summarised in Table 8.

From the range of statistical downscaling methods that are available, three of the most commonly-used methods are considered most appropriate for extremes and the needs of integrated assessment modelling:

- resampling of observed data conditioned by large-scale climate variables [106, 109, 118, 128-132];

- weather generator (with the option of conditioning parameters upon large-scale climate variables) [126, 133-144]; and,

- regression-based methods [144-153]. 
Table 8. Summary of the advantages and disadvantages of statistical downscaling for the construction of scenarios of extremes. $\boldsymbol{V}=$ advantage, $\boldsymbol{x}=$ disadvantage, $?=$ advantage/disadvantage of the method is uncertain.

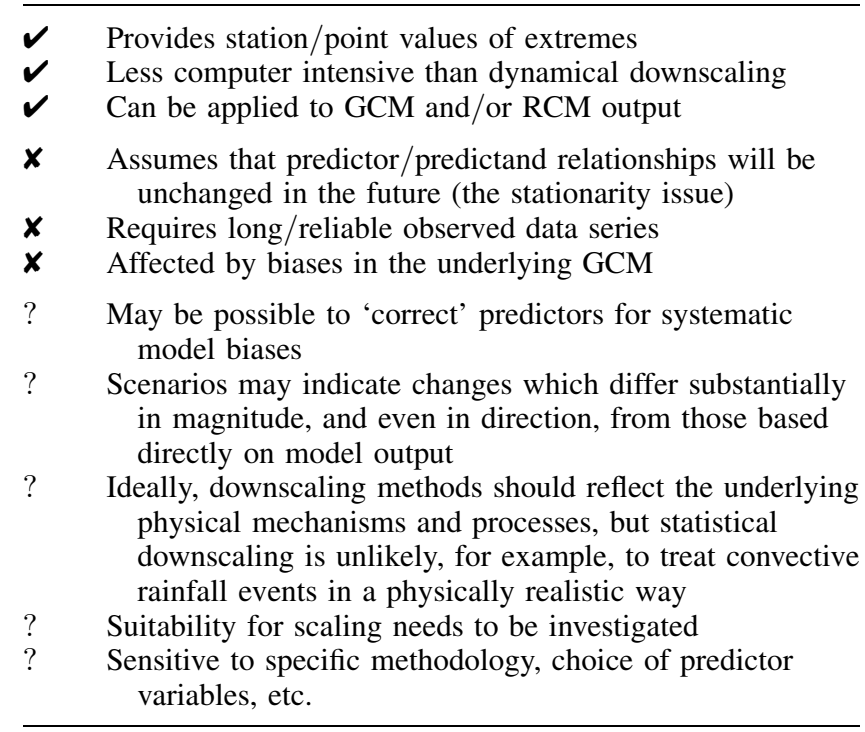

The specific advantages and disadvantages of these three methods are summarised in Table 9.

\subsection{Scenarios of Weather Extremes and Associated Uncertainties}

Comparative studies of the first three sources of uncertainty listed in Section 1 indicate that, for changes in mean climate, inter-model variability tends to be greater than inter-scenario or internal model variability, particularly over the earlier part of the 21 st century $[23,24,154,155]$. The uncertainties are, however, likely to depend on the variable being addressed. In an intercomparison of four RCMs, for example, Christensen et al. [156] concluded that inter-scenario uncertainties dominate in the case of mean temperature in Nordic regions.

Uncertainties in extreme event scenarios have rarely been studied. A recent exception is Palmer and Räisãnen [157] who used an ensemble of 19 GCMs to construct probabilistic scenarios of 'very wet,' defined as greater than the mean plus two standard deviations, European winters and Asian monsoon region summers. In a study of 20-year return period precipitation values in the Meuse region using output from a number of GCMs and RCMs, Booij [102] concludes that the uncertainties due to model errors and inter-model differences amount to $50 \%$ of the present-day return values (i.e., they are significantly larger than the projected change of $\sim 18 \%$ ). Further research is needed to determine which sources of uncertainty dominate for extremes.

The fourth source of uncertainty identified in Section 1, sub-grid scale forcings and processes, has not yet been adequately addressed in the literature, but may be particularly important for extreme weather events with high
Table 9. Summary of the advantages and disadvantages of three specific statistical downscaling methods for the construction of scenarios of extremes. $\boldsymbol{V}=$ advantage, $\boldsymbol{x}=$ disadvantage, ?=advantage/disadvantage of the method is uncertain.

1. Resampling of observed data conditioned by large-scale climate variables
$\checkmark \quad$ Provides self-consistent multi-site, multi-variate scenarios
$\checkmark \quad$ Multiple time series can be generated
$\boldsymbol{V} \quad$ Relatively simple method
$\boldsymbol{X}$ Magnitude (but not frequency) of the largest extreme is limited by the observations
x Difficult to extend to multiple predictors if sample size is limited
? Requires climate classification

2. Weather generator (with the option of conditioning the parameters upon large-scale climate variables)

$\checkmark \quad$ Long/multiple time series can be generated

$\boldsymbol{V}$ Provides self-consistent, multi-variate scenarios

$\boldsymbol{x}$ Variability and persistence tend to be underestimated (the overdispersion problem)

$\boldsymbol{x}$ May be difficult to perturb the parameters in a consistent way for future climates

? Methods are being developed for the production of selfconsistent multi-site scenarios, but tend to be complex and subject to technical/statistical problems

? May require climate classification for conditioning the parameters

3. Regression-based techniques

$\checkmark$ Climate classification is not required

$\checkmark \quad$ A wide range of potential predictors can be used

$\boldsymbol{x}$ Danger of over extrapolation in the future

$\boldsymbol{x} \quad$ Danger of overfitting

$\boldsymbol{X}$ Difficult to identify best suite of predictors for present-day and future climates

$\boldsymbol{X}$ Tend to perform less well for precipitation than temperature

? $\quad$ Stochastic elements can be introduced, e.g., to increase variability

temporal and spatial resolutions. RCMs provide information at the sub-GCM grid scale, so ensemble RCM output provides one way of exploring this issue [154]. However, the current resolution of RCMs, $50 \mathrm{~km} \times 50 \mathrm{~km}$ for HadRM3, is still relatively coarse for some extreme event processes, such as convective precipitation. Statistical downscaling methods provide station or point values and thus may provide another way of exploring this issue, but introduce additional uncertainties due to the methods themselves. Similarly, statistical manipulation methods which attempt to correct for model biases (Table 6) are also likely to introduce new uncertainties.

Another aspect of uncertainty which needs to be addressed concerns the relationship between the future climate-change uncertainties discussed above and multidecadal climate variability [20], i.e., the issue of signal-tonoise ratios (which is particularly important for determining the significance of projected climate changes and for detection and attribution studies). Changes in extreme events may be greater than changes in mean climate $[10,108]$, but 
because the natural variability of extremes is also greater than that of mean climate, the signal-to-noise ratio may be lower for extremes than for mean climate, making it more difficult to identify significant changes in extremes.

The associated uncertainties are dependent on the variable and spatial/temporal scale considered, generally increasing with increased resolution. The focus of this review is temperature and precipitation extremes. The uncertainties are likely to be greater for other variables such as wind, hail, fog, lightning, and storm surges. In the case of the UKCIP02 scenarios, for example, the uncertainties were considered so large, that the authors could not even assign a low level of confidence to the wind scenarios [60].

\section{OPTIONS FOR IMPEMENTING SCENARIOS OF EXTREMES IN IAMs}

From Sections 1 and 2, it is clear that there is a need for modification of the representation of climate information in IAMs in order to include extreme weather events. A range of potential methods for the construction of scenarios of extreme events is reviewed in Section 3, focusing on the advantages/disadvantages of the various methods and the issues which are most relevant to the needs of integrated assessment modelling. However, only limited intercomparisons of dynamical versus statistical approaches [99, 158-161] or of different statistical approaches [104-106, 124, 125] to downscaling have been carried out. Inter-comparisons focusing on extreme events are even rarer [110, 144]. These issues are being addressed by ongoing research programmes (funded by the European Commission, for example (http://www.cru.uea.ac.uk/projects/mps/)), but there are currently no systematic or comprehensive inter-comparisons or recommendations on 'best' methods. Thus, detailed validation and evaluation studies are required on a case-bycase basis before any of the methods reviewed in Section 3 can be used with confidence in integrated assessments.

Additional evaluation criteria need to be considered when using any of these scenario construction methods in IAMs as it is important that the key characteristics and advantages of IAMs, i.e., their computational efficiency and comprehensive nature, are not lost. In order to maintain computational efficiency and to limit the amount of data handled within IAMs, it is likely that much of the scenario analysis involving extreme weather events will be carried out offline. This will be particularly true for those extremes which must be considered at high spatial and temporal resolutions (see Section 1). These resolutions mean that large amounts of scenario data tend to be produced for extremes, compounded by the need to address the full range of uncertainty, using Monte Carlo and probabilistic approaches, for example. Thus considerable care is needed in identifying the key extreme events which should be incorporated in IAMs. Ideally, a limited range of indicators of extremes can be identified which are not highly correlated and which provide information on all relevant aspects, for example, changes in different seasons, changes in the magnitude of individual events and changes in persistence, of the key extremes. The appropriate extremes will, however, depend on the sectors being assessed and on the focus of the IAM. For planned adaptation, for example, projections of changes in the occurrence of experienced events, such as, for the UK, the 1953 storm surge event and the October 2000 floods, may be important.

The primary output from both dynamical and statistical downscaling methods focusing on extremes tends to be in the form of streams of daily data, which can conventionally be used in the following ways:

(i) relative changes can be added to baseline daily climatologies to create scenarios;

(ii) probability distribution functions can be constructed to reflect the uncertainties;

(iii) time series (either the downscaled series or adjusted baseline climatologies) can be provided.

Approach (i) could be used directly in IAMs, although appropriate and reliable global/regional gridded daily climatologies would be required. Approach (iii) could in theory be used directly in Biophysical-impact based IAMs (Section 2.4) and has the advantage of encompassing interannual variability. Some impacts modules would, however, need modification in order to handle daily data and there is a danger that this would make them too computationally demanding. These potential problems provide further justification for carrying out more of the scenario analysis offline, particularly if dynamical downscaling is the preferred option.

If extreme event scenario analysis is carried out offline, a mechanism is needed to tie this in with the IAM, in the same way that pattern-scaling of mean climate is tied to mean global temperature change in the current generation of IAMs (Section 2.2). For extremes, however, it may be appropriate to use some other large-scale variable (e.g., pressure patterns) as the scalar and/or to use a non-linear relationship (Section 3.3).

The structure of cost-benefit analysis IAMs incorporating damage functions (Section 2.3) is more immediately suitable for the incorporation of offline analysis of extremes than that of Biophysical impacts-based models. In the case of flooding events, for example, the cost-benefit analysis models require a conditional damage function (CDF) for estimation of the economic damage associated with a particular flood event given its probability of exceedence. Such a CDF could be constructed by: first, generating daily regional precipitation scenarios using dynamical or statistical downscaling; inputting these scenarios to a hydrological model in order to simulate flood peaks; fitting a distribution to the flood peaks to show the relationship between magnitude and probability of exceedence; and finally, translating this 
distribution in to the CDF for economic damages/probability of exceedence (Arnell, personal correspondence).

Ideally, this CDF should reflect the full cascade of uncertainty. Palmer and Räisãnen [157], for example, have recently demonstrated that use of a single deterministic scenario underestimates the risk of making the wrong hypothetical investment decision with respect to flooding, compared with the use of inter-model ensemble scenarios (based on output from 19 GCMs). This study focuses on Europe and the Asian monsoon region: it is concluded that larger model ensembles would be needed in order to assess risks at the country, for example, UK or Bangladesh, scale. Palmer and Räisãnen also conclude that GCMs may provide adequate information for large catchments such as the Ganges and Brahamaputra (a conclusion supported by Milly et al. [162] for catchments including the St Lawrence, Mississippi, Danube and $\mathrm{Ob}$ ), but downscaling to resolutions of tens of kilometres is required for smaller catchments.

In order to construct some CDFs (and for some impacts modules), it may be necessary to consider joint probabilities of extremes (although it is noted that no general statistical solutions for such problems are available [163]). It is estimated, for example, that $50 \%$ of the capital value of UK assets potentially at risk from sea, tidal and fluvial flooding lie within the River Thames region [164]. Flooding in estuaries in eastern Britain could occur due to the simultaneous occurrence of high sea level and high river flow [165]. Thus a CDF for overtopping of the Thames barrier would need to consider changes in storm surges (which can be estimated using a storm surge model combined with GCM/RCM output [166] or by statistical downscaling $[167,168])$, together with consistent (i.e., based on the same large-scale predictor variables) changes in river flooding (derived from downscaled precipitation scenarios input to a hydrological model). The joint probability of exceedence would then need to be calculated in order to construct the CDF.

Although the conventional approach for scenarios of extreme weather is to generate streams of daily data using dynamical or statistical downscaling and then calculate the frequency of occurrence and magnitude of extreme events, a more direct, but untested, approach to statistical downscaling could be used to construct CDFs for use in costbenefit analysis IAMs. This would entail identification of statistical relationships between the extremes themselves and the predictor variables. It has the potential advantage that these relationships might be stronger and more robust than those between the underlying daily temperature/ precipitation series and the same predictors. It would certainly have the advantage of producing smaller volumes of data and would be particularly suitable for the construction of probabilistic scenarios.

One of the major issues associated with the representation of extreme weather events in IAMs is the potential spatial scale mismatch between the scenario construction methods described in Section 3 and IAMs (Tables 2 and 3). There are two questions: first, is it physically meaningful to consider extremes at the IAM scale, and second, if it is, can the scenario construction methods provide information at the necessary scale? With respect to the first question, globallyaveraged extremes are not considered meaningful. Thus in IAMs that only operate at the global scale, i.e., the CETA and DICE cost-benefit analysis models (Table 3), it would not be appropriate to construct global damage functions using global indices of extremes. Global damage functions could, however, be constructed off-line using regional indices of extremes, as described earlier. Although the other cost-benefit analysis models listed in Table 3 are shown as having a regional spatial coverage, most of them (FUND, MERGE4.4 and MiniCAM) only calculate global temperature changes and would need modification in order to operate with damage functions incorporating regional climate information.

All the Biophysical-impacts models listed in Table 3 use grid-box information. Thus using higher-resolution RCM output rather than GCM output (i.e., dynamical downscaling) to derive the regional patterns of change would entail an increase in the volume of data handled, but would not require major modifications. The major constraints would be the availability of RCM output for all required regions and reliable gridded baseline climatologies (also required for validation). Tools such as the PRECIS (Providing REgional Climates for Impact Studies) regional modelling system being developed by the Hadley Centre [169] make this potentially feasible. Although most statistical downscaling methods focus on the station scale (because their ability to provide point-specific information is one of their major advantages), they could be applied at the grid-box scale of the baseline climatologies used in IAMs. This would, however, again require the availability of reliable gridded climatologies for all regions.

Rigorous testing of the methods identified here is needed in order to implement optimal methods for the incorporation of information about extreme weather events in IAMs. However, from the methods reviewed here, it is concluded that the less-computationally demanding statistical approaches to scenario construction, such as weather generators and patterns of change derived from RCMs, are likely to be more suitable for use in Biophysical impactsbased IAMs, while both dynamical and a number of different statistical approaches are potentially suitable for use in costbenefit analysis IAMs and are likely to be easier to implement because more analysis can be carried out offline in these economic-based models.

\section{ACKNOWLEDGEMENTS}

This work was funded as part of the Tyndall Centre for Climate Change Research projects on Estimating the Future Probabilities of Extreme Weather Events (IT1.16: CM 
Goodess, M Hulme and TJ Osborn) and A Blueprint for Integrated Assessment of Climate Change (IT1.3: C Hanson). The two anonymous reviewers are thanked for their comments on the manuscript.

\section{REFERENCES}

1. Rotmans, J.: IMAGE: An Integrated Model to Assess the Greenhouse Effect. Kluwer, The Netherlands, 1990.

2. Rotmans, J., Hulme, M. and Downing, T.E.: Climate Change Implications for Europe: An Application of the ESCAPE Model. Global Environ. Chang. 4 (1994), pp. 97-124.

3. Plambeck, E.L., Hope, C. and Anderson, J.: The PAGE95 Model: Integrating the Science and Economics of Global Warming. Energ. Econ. 19 (1997), pp. 77-101.

4. Peck, S.C. and Teisberg, T.J.: CETA: A Model for Carbon Emissions Trajectory Assessment. Energy J. 13 (1992), pp. 55-77.

5. Tol, R.S.J.: Spatial and Temporal Efficiency in Climate Policy: Applications of FUND. Environ. Resour. Econ. 14 (1999), pp. 33-49.

6. Matsuoka, Y., Kainuma, M. and Morita, T.: Scenario Analysis of Global Warming Using the Asian Pacific Integrated Model (AIM). Energ. Policy 23 (1995), pp. 357-371.

7. Kenny, G.J., Warrick, R.A., Campbell, B.D., Sims, G.C., Camilleri, M., Janeson, P.D., Mitchell, N.D., McPherson, H.G. and Salinger, M.J.: Investigating Climate Change Impacts and Thresholds: An Application of the CLIMPACTS Integrated Assessment Model for New Zealand Agriculture. Climatic Change 46 (2000), pp. 91-113.

8. Prinn, R., Jacoby, H., Sokolov, A., Wang, C., Xiao, X., Yang, Z., Eckhaus, R., Stone, P., Ellerman, D., Melillo, J., Fitzmaurice, J., Kicklighter, D., Holian, G. and Liu, Y.: Integrated Global System Model for Climate Policy Assessment: Feedbacks and Sensitivity Studies. Climatic Change 41 (1999), pp. 469-546.

9. Riha, S.J., Wilks, D.S. and Simoens, P.: Impact of Temperature and Precipitation Variability on Crop Model Predictions. Climatic Change 32 (1996), pp. 293-311.

10. Mearns, L.O., Rosenzweig, C. and Goldberg, R.: Mean and Variance Change in Climate Scenarios: Methods, Agricultural Applications, and Measures of Uncertainty. Climatic Change 35 (1997), pp. 367-396.

11. Cramer, W., Doherty, R., Hulme, M. and Viner, D. (eds.): Climate Scenarios for Agricultural and Ecosystem Impacts. Proceedings of the EU Concerted Action Initiative ECLAT-2 Workshop 2, Potsdam, Germany October 13th-15th, 1999. Climatic Research Unit, Norwich, UK, 2000

12. Karl, T.R., Nicholls, N. and Ghazi, A. (eds.): Weather and Climate Extremes: Changes, Variations and a Perspective from the Insurance Industry. Climatic Change 42 (1999), pp. 1-349.

13. Beersma, J., Agnew, M.D., Viner, D. and Hulme, M. (eds.): Climate Scenarios for Water-Related and Coastal Impacts. Proceedings of the EU Concerted Action Initiative ECLAT-2 Workshop 3, KNMI, Netherlands, May 10-12th, 2000. Climatic Research Unit, Norwich, UK, 2000.

14. Chartered Insurance Institute (CII): Climate Change and Insurance. Chartered Insurance Institute, London, UK, 2001.

15. Warren, R.: A Blueprint for Integrated Assessment of Climate Change. Tyndall Centre Technical Report 1, 2002.

16. Frich, P., Alexander, L.V., Della-Marta, P., Gleason, B., Haylock, M., Klein Tank, A.M.G. and Peterson, T.: Observed Coherent Changes in Climatic Extremes During the Second Half of the Twentieth Century. Climate Res. 19 (2002), pp. 193-212.

17. Goodess, C.M., Hulme, M. and Osborn, T.J.: The Identification and Evaluation of Suitable Scenario Development Methods for the Estimation of Future Probabilities of Extreme Weather Events.
Tyndall Centre for Climate Change Research, Working Paper 6, TWP6, 2001.

18. Hulme, M. and Brown, O.: Portraying Climate Scenario Uncertainties in Relation to Tolerable Regional Climate Change. Climate Res. 10 (1998), pp. 1-14.

19. Hulme, M. and Carter, T.R., 1999: Representing Uncertainty in Climate Change Scenarios and Impact Studies. In: T.R. Carter, M. Hulme and D. Viner (eds.): Representing Uncertainty in Climate Change Scenarios and Impact Studies. ECLAT-2 Workshop Report No. 1, Helsinki, Finland, 14-16 April 1999. Climatic Research Unit, UEA, Norwich, UK, 1999, pp. 11-37.

20. Hulme, M., Barrow, E.M., Arnell, N.W., Harrison, P.A., Johns, T.C. and Downing, T.E.: Relative Impacts of Human-induced Climate Change and Natural Climate Variability. Nature 397 (1999), pp. 688-691.

21. Katz, R.W.: Techniques for Estimating Uncertainty in Climate Change Scenarios and Impact Studies. In: T.R. Carter, M. Hulme and D. Viner (eds.): Representing Uncertainty in Climate Change Scenarios and Impact Studies, ECLAT-2 Workshop Report No. 1, Helsinki, Finland, 14-16 April 1999. Climatic Research Unit, UEA, Norwich, UK, 1999, pp. $38-53$.

22. Mitchell, T.D. and Hulme, M.: Predicting Regional Climate Change: Living With Uncertainty. Prog. Phys. Geog. 23 (1999), pp. 57-78.

23. Giorgi, F. and Francisco, R.: Uncertainties in Regional Climate Change Prediction: A Regional Analysis of Ensemble Simulations with the HADCM2 Coupled AOGCM. Clim. Dynam. 16 (2000), pp. 169-182.

24. Giorgi, F. and Francisco, R.: Evaluating Uncertainties in the Prediction of Regional Climate Change. Geophys. Res. Lett. 27 (2000), pp. 1295-1298.

25. Jones, R.N.: Managing Uncertainty in Climate Change Projections Issues for Impact Assessment. Climatic Change 45 (2000), pp. 403-419.

26. Jones, R.N.: Analysing the Risk of Climate Change Using an Irrigation Demand Model. Climate Res. 14 (2000), pp. 89-100.

27. New, M. and Hulme, M.: Representing Uncertainty in Climate Change Scenarios: A Monte-Carlo Approach. Int. Assess. 1 (2000), pp. 203-213.

28. Visser, H., Folkert, R.J.M., Hoekstra, J. and de Wolff, J.J.: Identifying Key Sources of Uncertainty in Climate Change Projections. Climatic Change 45 (2000), pp. 421-457.

29. Räisänen, J. and Palmer, T.N.: A Probability and Decision-model Analysis of a Multi-model Ensemble of Climate Change Simulations. J. Climate 14 (2001), pp. 3212-3226.

30. Houghton, J.T., Ding, Y., Griggs, D.J., Noguer, M., van der Linden, P.J. and Xiaosu, D. (eds.): Climate Change 2001: The Scientific Basis, Contribution of Working Group I to the Third Assessment Report of the Intergovernmental Panel on Climate Change. Cambridge University Press, UK, 2001.

31. McCarthy, J.J., Canziani, O.F., Leary, N.A., Dokken, D.J. and White, K.S. (eds): Climate Change 2001: Impacts, Adaptation and Vulnerability, Contribution of Working Group II to the Third Assessment Report of the Intergovernmental Panel on Climate Change. Cambridge University Press, UK, 2001.

32. Allen, M., Raper, S. and Mitchell, J.: Uncertainty in the IPCC's Third Assessment Report. Science 293 (2001), pp. 430-433.

33. Andronova, N.G. and Schlesinger, M.E.: Objective Estimation of the Probability Density Function for Climate Sensitivity. J. Geophys. Res. 106 (2001), pp. 22605-22611.

34. Reilly, J., Stone, P.H., Forest, C.E., Webster, M.D., Jacoby, H.D. and Prinn, R.G.: Uncertainty and Climate Change Assessments. Science 293 (2001), pp. 430-433.

35. Wigley, T.M.L. and Raper, S.C.B.: Interpretation of High Projections for Global-mean Warming. Science 293 (2001), pp. 451-454.

36. Katz, R.W.: Techniques for Estimating Uncertainty in Climate Change Scenarios and Impact Studies. Climate Res. 20 (2002), pp. 167-185.

37. Stott, P.A. and Kettleborough, J.A.: Origins and Estimates of Uncertainty in Predictions of Twenty-first Century Temperature Rise. Nature 416 (2002), pp. 723-726. 
38. Knutti, R., Stocker, T.F., Joos, F. and Plattner, G.-K.: Constraints on Radiative Forcing and Future Climate Change from Observations and Climate Model Ensembles. Nature 416 (2002), pp. 719-723.

39. Bruce, J.P., Lee, H. and Haites, E.F. (eds.): Climate Change 1995: Economic and Social Dimensions of Climate Change. Contribution of Working Group III to the Second Assessment Report of the Intergovernmental Panel on Climate Change. Cambridge University Press, UK, 1996.

40. Keller, K., Tan, K., Morel, F.M.M. and Bradford, D.F.: Preserving the Ocean Circulation: Implications for Climate Policy. Climatic Change 47 (2000), pp. 17-43.

41. Schneider, S.H. and Thompson, S.L.: A Simple Climate Model used in Economic Studies of Global Change. In: S.J. Decanio, R.B. Howarth, A.H. Sanstad, S.H. Schneider and S.L. Thompson (eds.): New Directions in the Economics and Integrated Assessment of Global Climate Change. PEW Center on Global Climate Change, 2000, pp. 59-79.

42. Mastrandrea, M.D. and Schneider, S.H.: Integrated Assessment of Abrupt Climatic Changes. Climate Policy 1 (2001), pp. 433-449.

43. Bruckner, T., Hooss, G., Füssel, H.-M. and Hasselmann, K.: Climate System Modelling in the Framework of the Tolerable Windows Approach: The ICLIPS Climate Model. Climatic Change 1-2 (2003), pp. 119-137.

44. Kropp, J., Zickfeld, K. and Eisenack, K.: Assessment and Management of Critical Events: The Breakdown of Marine Fisheries and the North Atlantic Thermohaline Circulation. In: A. Bunde, J. Kropp and H.-J. Schellnhuber (eds.): The Science of Disasters (2002) Chapter 6, Springer, New York.

45. Meadows, D.H., Richardson, J. and Bruckmann, G.: Groping in the Dark: The First Decade of Global Modelling. Wiley, Chichester, UK, 1982.

46. Dowlatabadi, H.: Integrated Assessment Models of Climate Change An Incomplete Overview. Energ. Policy 23 (1995), pp. 289-296.

47. Rosenberg, N.J. (ed.): Towards an Integrated Impact Assessment of Climate Change: The MINK Study. Kluwer, Boston, 1993.

48. Nakicenovic, N. and Swart, R. (eds.): Emissions Scenarios. 2000. Special Report of the Intergovernmental Panel on Climate Change. Cambridge University Press, UK, 2000.

49. Williams, L.J., Shaw, D. and Mendelsohn, R.: Evaluating GCM Output with Impact Models. Climatic Change 39 (1998), pp. 111-133.

50. Yohe, G.W. and Schlesinger, M.E.: Sea-Level Change: The Expected Economic Cost of Protection or Abandonment in the United States. Climatic Change 38 (1998), pp. 447-472.

51. Wigley, T.M.L., Raper, S.C.B., Hulme, M. and Smith, S.: The MAGICC/SCENGEN Climate Scenario Generator: Version 2.4. Technical Manual. Climatic Research Unit, UEA, Norwich, UK, 2000.

52. Alcamo, J. (ed.): IMAGE 2.0: Integrated Modeling of Global Climate Change. Kluwer Academic Publishers, London, 1994.

53. Manne, A.S. and Richels, R.G.: US Rejection of the Kyoto Protocol: The Impact on Compliance Costs and $\mathrm{CO}_{2}$ Emissions. Stanford University Energy Modelling Forum (EMF) Meeting on Burden Sharing and the Costs of Mitigation, Snowmass, Colorado, August 6, 2001.

54. Hulme, M., Raper, S.C.B. and Wigley, T.M.L.: An Integrated Framework to Address Climate Change (ESCAPE) and Further Developments of the Global and Regional Climate Modules. Energ. Policy 23 (1995), pp. 347-355.

55. Santer, B.D., Wigley, T.M.L., Schlesinger, M.E. and Mitchell, J.F.B.: Developing Climate Scenarios from Equilibrium GCM Results. MPI Report 47, Hamburg, 1990.

56. Mitchell, J.F.B., Johns, T.C., Eagles, M., Ingram, W.J. and Davis, R.A.: Towards the Construction of Climate Change Scenarios. Climatic Change 41 (1999), pp. 547-581.

57. Hulme, M., Wigley, T.M.L., Barrow, E.M., Raper, S.C.B., Centella, A., Smith, S. and Chipanshi, A.C.: Using a Climate Scenario Generator for Vulnerability and Adaptation Assessments, MAGICC and SCENGEN Version 2.4 Workbook. Climatic Research Unit, Norwich, UK, 2000.
58. Huntingford, C. and Cox, P.M.: An Analogue Method to Derive Additional Climate Change Scenarios from Existing GCM Simulations. Clim. Dynam. 16 (2000), pp. 575-586.

59. Mitchell, T.D.: An Investigation of the Pattern Scaling Technique for Describing Future Climates. PhD Thesis, University of East Anglia, Norwich, 2000.

60. Hulme, M., Jenkins, G.J., Lu, X., Turnpenny, J.R., Mitchell, T.D., Jones, R.G., Lowe, J., Murphy, J.M., Hassell, D., Boorman, P., McDonald, R. and Hill, S.: Climate Change Scenarios for the United Kingdom: The UKCIP02 Scientific Report. Tyndall Centre for Climate Change Research, School of Environmental Sciences, University of East Anglia, Norwich, UK, 2002.

61. Holt, T.: Construction of Climate Change Scenarios by Linking GCM and STUGE Output. Technical Note No. 2, UK Department of the Environment Climate Change Impacts/Predictive Modelling LINK, Contract Reference Number PECD 7/12/96, 1993.

62. Gates, W.L., Mitchell, J.F.B., Boer, G.J., Cubasch, U. and Meleshko, V.P.: Climate Modelling, Climate Prediction and Model Validation. (eds.) In: J.T. Houghton, B.A. Callander and S.K. Varney (eds.): Climate Change 1992: The Supplementary Report to the IPCC Scientific Assessment. Cambridge University Press, Cambridge, 1992, pp. 97-134.

63. Santer, B.D., Wigley, T.M.L. and Jones, P.D.: Correlation Methods in Fingerprint Detection Studies. Clim. Dynam. 8 (1993), pp. 265-276.

64. Tol, R.S.J.: On the Optimal Control of Carbon Dioxide Emissions: An Application of FUND. Environ. Model. Assess. 2 (1997), pp. 151-163.

65. Parry, M.L. and Carter, T.: Climate Impact and Adaptation Assessment: A Guide to the IPCC Approach. Earthscan Publications Ltd, London, 1998.

66. Peck, S.C. and Teisberg, T.J.: $\mathrm{CO}_{2}$ Emissions Control: Comparing Policy Instruments. Energ. Policy 21 (1993), pp. 222-230.

67. Manne, A., Mendelsohn, R. and Richels, R.G.: MERGE A Model for Evaluating Regional and Global Effects of GHG Reduction Policies. Energ. Policy 23 (1995), pp. 17-34.

68. Tol, R.S.J.: Safe Policies in an Uncertain Climate: An Application of FUND. Global Environ. Chang. 9 (1999), pp. 221-232.

69. Cox, P.M., Betts, R.A., Jones, C.D., Spall, S.A. and Totterdell, I.J.: Acceleration of Global Warming due to Carbon-cycle Feedbacks in a Coupled Climate Model. Nature 408 (2000), pp. 184-187.

70. White, A., Cannell, M.G.R. and Friend, A.D.: Climate Change Impacts on Ecosystems and the Terrestrial Carbon Sink: A New Assessment. Global Environ. Chang. 9 (1999), pp. S21-S30.

71. Van Minnen, J.G., Leemans, R. and Ihle, F.: Defining the Importance of Including Transient Ecosystem Responses to Simulate C-cycle Dynamics in a Global Change Model. Glob. Change Biol. 6 (2000), pp. 595-611.

72. Leemans, R., van Amstel, A., Battjes, C., Kreileman, E. and Toet, S.: The Land Cover and Carbon Cycle Consequences of Large-scale Utilizations of Biomass as an Energy Source. Global Environ. Chang. 6 (1996), pp. 335-357.

73. New, M., Hulme, M. and Jones, P.: Representing Twentieth-century Space-time Climate Variability. Part I: Development of a 1961-90 Mean Monthly Terrestrial Climatology. J. Climate 12 (1999), pp. 829-856.

74. Kreileman, G.J.J. and Berk, M.M.: The Safe Landing Analysis: Users Manual. RIVM Report No. 481508003, 1997.

75. Leimbach, M., Bruckner, T., Füssel, H.-M., Gritsevskii, A., Klepper, G., Sands, R., Schrattenholzer, L., Springer, K. and Toth, F.: ICLIPS Integrated Assessment of Climate Protection Strategies: Political and Economic Contributions. Potsdam Institute for Climate Impact Research, Research Report 29641 815, 2000.

76. Toth, F.L., Bruckner, T., Füssel, H.M., Leimbach, M., Petschel-Held, G. and Schellnhuber, H.J.: Exploring Options for Global Climate Policy: A New Analytical Framework. Environment 44 (2002), pp. 22-34.

77. Toth, F.L.: Climate Policy in Light of Climate Science: The ICLIPS Project. Climatic Change 56 (2003), pp. 7-36. 
78. Füssel, H.-M. and van Minnen, J.G.: Climate Impact Response Functions for Terrestrial Ecosystems. Int. Assess. 2 (2001), pp. 183-197.

79. Toth, F.L. (ed.): ICLIPS Special Issue. Climatic Change 56 (2003), pp. 1-226.

80. Füssel, H.-M., Toth, F.L., van Minnen, J.G. and Kaspar, F.: Climate Impact Response Functions as Impact Tools in the Tolerable Windows Approach. Climatic Change 56 (2003), pp. 91-117.

81. Matsuoka, Y., Morita, T. and Kainama, M.: Integrated Assessment Model of Climate Change: The AIM Approach in Present and Future of Modelling Global Environmental Change. In: T. Matsuno and H. Kida (eds.): Toward Integrated Modelling. Terrapub, 2001, pp. 339-361.

82. Morita, T., Kainuma, M., Harasawa, H. and Kai, K.: Asian-Pacific Integrated Model for Evaluating Policy Options to Reduce Greenhouse Gas Emissions and Global Warming Impacts. AIM Interim Report, National Institute for Environmental Studies, Japan, 1994.

83. Kenny, G.J., Warrick, R.A., Mitchell, N.D., Mullan, A.B. and Salinger, M.J.: CLIMPACTS: An Integrated Model for Assessment of the Effects of Climate Change on the New Zealand Environment. $J$. Biogeogr. 22 (1995), pp. 883-895.

84. Forest, C.E., Allen, M.R., Sokolov, A.P. and Stone, P.H.: Constraining Climate Model Properties using Optimal Fingerprint Detection Methods. Clim. Dynam. 18 (2001), pp. 277-295.

85. Plambeck, E.L. and Hope, C.: PAGE95: An Updated Valuation of the Impacts of Global Warming. Energ. Policy 24 (1996), pp. 783-793.

86. McKay, M.D., Conover, W.J. and Whiteman, D.E.: Report on the Application of Statistical Techniques to the Analysis of Computer Codes. Technical Report LA-NUREG-6526-MS. Los Alamos National Laboratory, Los Alamos, NM, 1976.

87. McKay, M.D.: Latin Hypercube Sampling as a Tool in Uncertainty Analysis of Computer Models. Proceedings of the Winter Simulation Conference, Arlington, Virginia, December 13-16, LAUR 92-2338, 1992.

88. Scott, M.J., Sands, R.D., Edmonds, J., Liebetrau, A.M. and Engel, D.W.: Uncertainty in Integrated Assessment Models: Modeling with MiniCAM 1.0. Energ. Policy 27 (1999), pp. 855-879.

89. Kharin, V.V. and Zwiers, F.W.: Changes in the Extremes in an Ensemble of Transient Climate Simulations with a Coupled Atmosphere-ocean GCM. J. Climate 13 (2000), pp. 3760-3788.

90. Meehl, G.A., Zwiers, F., Evans, J., Knutson, T., Mearns, L. and Whetton, P.: Trends in Extreme Weather and Climate Events: Issues Related to Modeling Extremes in Projections of Future Climate Change. B. Am. Meteorol. Soc. 81 (2000), pp. 427-436.

91. Buishand, T.A. and Beersma, J.J.: Statistical Tests for Comparison of Daily Variability in Observed and Simulated Climates. J. Climate 9 (1996), pp. 2538-2550.

92. Beersma, J.J. and Buishand, T.A.: A Simple Test for Equality of Variances in Monthly Climate Data. J. Climate 12 (1999), pp. $1770-1779$.

93. Boer, G.J., Flato, G.M. and Ramsden, D.: A Transient Climate Change Simulation with Greenhouse Gas and Aerosol Forcing: Projected Climate to the Twenty-first Century. Clim. Dynam. 16 (2000), pp. $427-450$.

94. Gregory, J.M. and Mitchell, J.F.B.: Simulation of Daily Variability of Surface Temperature and Precipitation Over Europe in the Current and $2 \times \mathrm{CO}_{2}$ Climates Using the UKMO Climate Model. Q. J. Roy. Meteor. Soc. 121 (1995), pp. 1451-1476.

95. Hennessy, K.J., Gregory, J.M. and Mitchell, J.F.B.: Changes in Daily Precipitation Under Enhanced Greenhouse Conditions. Clim. Dynam. 13 (1997), pp. 667-680.

96. Wetherald, R.T. and Manabe, S.: Detectability of Summer Dryness Caused by Greenhouse Warming. Climatic Change 43 (1999), pp. $495-511$.

97. Schär, C., Frei, C., Lüthi, D. and Davies, H.C.: Surrogate Climatechange Scenarios for Regional Climate Models. Geophys. Res. Lett. 23 (1996), pp. 669-672.
98. Frei, C., Schär, C., Lüthi, D. and Davies, H.C.: Heavy Precipitation Processes in a Warmer Climate. Geophys. Res. Lett. 25 (1998), pp. 1431-1434.

99. Mearns, L.O., Bogardi, I., Giorgi, F., Matyasovszky, I. and Palecki, M.: Comparison of Climate Change Scenarios Generated from Regional Climate Model Experiments and Statistical Downscaling. J. Geophys. Res. 104 (1999), pp. 6603-6621.

100. Durman, C.F., Gregory, J.M., Hassell, D.C., Jones, R.G. and Murphy, J.M.: A Comparison of Extreme European Daily Precipitation Simulated by a Global and a Regional Climate Model for Present and Future Climates. Q. J. Roy. Meteor. Soc. 127 (2001), pp. 1005-1015.

101. Jones, P.D. and Reid, P.A.: Assessing Future Changes in Extreme Precipitation over Britain Using Regional Climate Model Integrations. Int. J. Climatol. 21 (2001), pp. 1337-1356.

102. Booij, M.J.: Extreme Daily Precipitation in Western Europe with Climate Change at Appropriate Spatial Scales. Int. J. Climatol. 22 (2002), pp. 69-85.

103. Osborn, T.J., Hulme, M., Jones, P.D. and Basnett, T.A.: Observed Trends in the Daily Intensity of United Kingdom Precipitation. Int. J. Climatol. 20 (2000), pp. 347-364.

104. Hewitson, B.C. and Crane, R.G.: Climate Downscaling: Techniques and Application. Climate Res. 7 (1996), pp. 85-95.

105. Wilby, R.L., Wigley, T.M.L., Conway, D., Jones, P.D., Hewitson, B.C., Main, J. and Wilks, D.S.: Statistical Downscaling of General Circulation Model Output: A Comparison of Methods. Water Resour. Res. 34 (1998), pp. 2995-3008.

106. Zorita, E. and von Storch, H.: The Analog Method as a Simple Statistical Downscaling Technique: Comparison With More Complicated Methods. J. Climate 12 (1999), pp. 2474-2489.

107. Wagner, D.: Scenarios of Extreme Temperature Events. Climatic Change 33 (1996), pp. 385-407.

108. Wagner, D.: Assessment of the Probability of Extreme Weather Events and Their Potential Effects in Large Conurbations. Atmos. Environ. 33 (1999), pp. 4151-4155.

109. Brandsma, T. and Buishand, T.A.: Simulation of Extreme Precipitation in the Rhine Basin by Nearest-neighbour Resampling. Hydrol. Earth Syst. Sc. 2 (1998), pp. 195-209.

110. Kyselý, J.: Comparison of Extremes in GCM-simulated, Downscaled and Observed Central-European Temperature Series. Climate Res. 20 (2002), pp. 211-222.

111. Smith, J.B. and Hulme, M.: Climate Change Scenarios. In: J. Feenstra, I. Burton, J.B. Smith and R.S.J. Tol (eds.): Handbook on Methods of Climate Change Impacts Assessment and Adaptation Strategies, Version 2. UNEP/IES, Amsterdam, 1998.

112. Semenov, M.A. and Brooks, R.J.: Spatial Interpolation of the LARSWG Stochastic Weather Generator in Great Britain. Climate Res. 11 (1999), pp. 137-148.

113. Zwiers, F.W. and Kharin, V.V.: Changes in the Extremes of the Climate Simulated by CCC GCM2 under $\mathrm{CO}_{2}$ Doubling. J. Climate 11 (1998), pp. 2200-2222.

114. Osborn, T.J. and Hulme, M.: Development of a Relationship Between Stations and Grid-box Rainday Frequencies for Climate Model Evaluation. J. Climate 10 (1997), pp. 1885-1908.

115. Osborn, T.J. and Hulme, M.: Evaluation of the European Daily Precipitation Characteristics from the Atmospheric Model Intercomparison Project. Int. J. Climatol. 18 (1998), pp. 505-522.

116. Wilks, D.S.: Adapting Stochastic Weather Generation Algorithms for Climate Change Studies. Climatic Change 22 (1992), pp. 67-84.

117. Bates, B.C., Charles, S.P., Sumner, N.R. and Fleming, P.M.: Climate Change and its Hydrological Implications for South Australia. T. Roy. Soc. South Aust. 118 (1994), pp. 35-43.

118. Cubasch, U., von Storch, H., Waszkewitz, J. and Zorita, E.: Estimates of Climate Change in Southern Europe Derived from Dynamical Climate Model Output. Climate Res. 7 (1996), pp. 129-149.

119. Christensen, J.H., Machenhauer, B., Jones, R.G., Schär, C., Ruti, P.M., Castro, M. and Visconti, G.: Validation of Present-day 
Regional Climate Simulations over Europe: LAM Simulations with Observed Boundary Conditions. Clim. Dynam. 13 (1997), pp. 489-506.

120. Jones, R.G., Murphy, J.M., Noguer, M. and Keen, A.B.: Simulation of Climate Change Over Europe Using a Nested Regional-climate Model. II: Comparison of Driving and Regional Model Responses to a Doubling of Carbon Dioxide. Q. J. Roy. Meteor. Soc. 123 (1997), pp. 265-292.

121. Voss, R., May, W. and Roeckner, E.: Enhanced Resolution Modelling Study on Anthropogenic Climate Change: Changes in Extremes of the Hydrological Cycle. Int. J. Climatol. 22 (2002), pp. 755-777.

122. Hulme, M., Crossley, J. and Lu, X.: An Exploration of Regional Climate Change Scenarios for Scotland. The Scottish Executive Central Research Unit, 2001.

123. Rummukainen, M., Räisänen, J., Bringfelt, B., Ullerstig, A., Omstedt, A., Willén, U., Hansson, U. and Jones, C.: A Regional Climate Model for Northern Europe: Model Description and Results from the Downscaling of Two GCM Control Simulations. Clim. Dynam. 17 (2001), pp. 339-359.

124. Wilby, R.L. and Wigley, T.M.L.: Downscaling General Circulation Model Output: A Review of Methods and Limitations. Prog. Phys. Geog. 21 (1997), pp. 530-548.

125. Wilks, D.S. and Wilby, R.L.: The Weather Generation Game: A Review of Stochastic Weather Models. Prog. Phys. Geog. 23 (1999), pp. 329-357.

126. Goodess, C.M.: The Construction of Daily Rainfall Scenarios for Mediterranean Sites Using a Circulation-type Approach to Downscaling. PhD Thesis, University of East Anglia, Norwich, 2000.

127. Buishand, T.A. and Brandsma, T.: Dependence of Precipitation on Temperature at Florence and Livorno (Italy). Climate Res. 12 (1999), pp. 53-63.

128. Zorita, E., Hughes, J.P., Lettenmaier, D.P. and von Storch, H.: Stochastic Characterization of Regional Circulation Patterns for Climate Model Diagnosis and Estimation of Local Precipitation. $J$. Climate 8 (1995), pp. 1023-1042.

129. Conway, D. and Jones, P.D.: The Use of Weather Types and Air Flow Indices for GCM Downscaling. J. Hydrol. 212-213 (1998), pp. 348-361.

130. Schnur, R. and Lettenmaier, D.P.: A Case Study of Statistical Downscaling in Australia Using Weather Classification by Recursive Partitioning. J. Hydrol. 212-213 (1998), pp. 362-379.

131. Palutikof, J.P., Goodess, C.M., Watkins, S.J. and Holt, T.: Generating Rainfall and Temperature Scenarios at Multiple Sites: Examples from the Mediterranean. J. Climate 15 (2002), pp. 3529-3548.

132. Wilby, R.L., Tomlinson, O.J. and Dawson, C.W.: Multi-site Simulation of Precipitation by Conditional Resampling. Climate Res. 23 (2003), pp. 183-194.

133. Hay, L.E., McCabe, G.J., Wolock, D.M. and Ayers, M.A.: Simulation of Precipitation by Weather Type Analysis. Water Resour. Res. 27 (1991), pp. 493-501.

134. Wilson, L.L., Lettenmaier, D.P. and Wood, E.F.: Simulation of Daily Precipitation in the Pacific Northwest Using a Weather Classification Scheme. Surv. Geophys. 12 (1991), pp. 127-142.

135. Bardossy, A. and Plate, E.J.: Space-time Model for Daily Rainfall Using Atmospheric Circulation Patterns. Water Resour. Res. 28 (1992), pp. 1247-1259.

136. Hay, L.E., McCabe, G.J., Wolock, D.M. and Ayers, M.A.: Use of Weather Types to Disaggregate General Circulation Model Predictions. J. Geophys. Res. 97 (1992), pp. 2781-2790.

137. Wilson, L.L., Lettenmaier, D.P. and Skyllingstad, E.: A Hierarchical Stochastic Model of Large-scale Atmospheric Circulation Patterns and Multiple Station Daily Precipitation. J. Geophys. Res. 97 (1992), pp. 2791-2809.

138. Bogardi, I., Matyasovszky, I., Bardossy, A. and Duckstein, L.: Application of a Space-time Stochastic Model for Daily Precipitation Using Atmospheric Circulation Patterns. J. Geophys. Res. 98 (1993), pp. $16653-16667$.
139. Hughes, J.P., Lettenmaier, D.P. and Guttorp, P.: A Stochastic Approach for Assessing the Effect of Changes in Synoptic Circulation Patterns on Gauge Precipitation. Water Resour. Res. 29 (1993), pp. 3303-3315.

140. Hughes, J.P. and Guttorp, P.: A Class of Stochastic Models for Relating Synoptic Atmospheric Patterns to Regional Hydrologic Phenomena. Water Resour. Res. 30 (1994), pp. 1535-1546.

141. Wilby, R.L., Greenfield, B. and Glenny, C.: A Coupled Synoptichydrological Model for Climate Change Impact Assessment. J. Hydrol. 153 (1994), pp. 265-290.

142. Goodess, C.M. and Palutikof, J.P.: Development of Daily Rainfall Scenarios for Southeast Spain Using a Circulation-type Approach to Downscaling. Int. J. Climatol. 18 (1998), pp. 1051-1083.

143. Corte-Real, J., Xu, H. and Qian, B.: A Weather Generator for Obtaining Daily Precipitation Scenarios Based on Circulation Patterns. Climate Res. 13 (1999), pp. 61-75.

144. Huth, R., Kyselý, J. and Dubrovský, M.: Time Structure of Observed, GCM-simulated, Downscaled, and Stochastically Generated Daily Temperature Series. J. Climate 14 (2001), pp. 4047-4061.

145. Schubert, S. and Henderson-Sellers, A.: A Statistical Model to Downscale Local Daily Temperature Extremes from Synoptic-scale Atmospheric Circulation Patterns in the Australian Region. Clim. Dynam. 13 (1997), pp. 223-234.

146. Winkler, J.A., Palutikof, J.P., Andresen, J.A. and Goodess, C.M.: The Simulation of Daily Temperature Time Series from GCM Output. Part II: Sensitivity Analysis of an Empirical Transfer Function Methodology. J. Climate 10 (1997), pp. 2514-2532.

147. Kilsby, C.G., Cowpertwait, P.S.P., O'Connell, P.E. and Jones, P.D.: Predicting Rainfall Statistics in England and Wales Using Atmospheric Circulation Variables. Int. J. Climatol. 18 (1998), pp. 523-539.

148. Schubert, S.: Downscaling Local Extreme Temperature Changes in South-eastern Australia from the CSIRO Mark2 GCM. Int. J. Climatol. 18 (1998), pp. 1419-1438.

149. Wilby, R.L.: Statistical Downscaling of Daily Precipitation Using Daily Airflow and Seasonal Teleconnection Indices. Climate Res. 10 (1998), pp. 163-178.

150. Wilby, R.L., Hassan, H. and Hanaki, K.: Statistical Downscaling of Hydrometeorlogical Variables Using General Circulation Model Output. J. Hydrol. 205 (1998), pp. 1-19.

151. Busuioc, A., von Storch, H. and Schnur, R.: Verification of GCMGenerated Regional Seasonal Precipitation for Current Climate and of Statistical Downscaling Estimates Under Changing Climate Conditions. J. Climate 12 (1999), pp. 258-272.

152. Beckman, B.-R. and Buishand, T.A.: Statistical Downscaling Relationships for Precipitation in the Netherlands and North Germany. Int. J. Climatol. 22 (2002), pp. 15-32.

153. Wilby, R.L., Dawson, C.W. and Barrow, E.M.: SDSM - A Decision Support Tool for the Assessment of Regional Climate Change Impacts. Environ. Modell. Softw. 17 (2002), pp. 145-157.

154. Dutton, J.F. and Barron, E.J.: Intra-annual and Interannual Ensemble Forcing of a Regional Climate Model. J. Geophys. Res. 105 (2000), pp. 29523-29538.

155. Bergström, S., Carlsson, B., Gardelin, M., Lindström, G., Pettersson, A. and Rummukainen, M.: Climate Change Impacts on Runoff in Sweden Assessments by Global Climate Models, Dynamical Downscaling and Hydrological Modelling. Climate Res. 16 (2001), pp. 101-112.

156. Christensen, J.H., Räisãnen, J., Iversen, T., Bjørge, D., Christensen, O.B. and Rummukainen, M.: A Synthesis of Regional Climate Change Simulations - A Scandinavian Perspective. Geophys. Res. Lett. 28 (2001), pp. 1003-1006.

157. Palmer, T.N. and Räisãnen, J.: Quantifying the Risk of Extreme Seasonal Precipitation Events in a Changing Climate. Nature 415 (2002), pp. 512-514.

158. Kidson, J.W. and Thompson, C.S.: A Comparison of Statistical and Model-Based Downscaling Techniques for Estimating Local Climate Variations. J. Climate 11 (1998), pp. 735-753. 
159. Charles, S.P., Bates, B.C. and Hughes, J.P.: A Spatiotemporal Model for Downscaling Precipitation Occurrence and Amounts. J. Geophys. Res. 104 (1999), pp. 31657-31669.

160. Murphy, J.: An Evaluation of Statistical and Dynamical Techniques for Downscaling Local Climate. J. Climate 12 (1999), pp. 2256-2284.

161. Murphy, J.M.: Predictions of Climate Change over Europe Using Statistical and Dynamical Downscaling Techniques. Int. J. Climatol. 20 (2000), pp. 489-501.

162. Milly, P.C.D., Wetherald, R.T., Dunne, K.A. and Delworth, T.L.: Increasing Risk of Great Floods in a Changing Climate. Nature 415 (2002), pp. 514-517.

163. Institute of Hydrology (IoH): Flood Estimation Handbook. Institute of Hydrology, Wallingford, Oxfordshire, Volume 1, UK, 1999.

164. Halcrow Group Ltd.: National Appraisal of Assets at Risk from Flooding and Coastal Erosion, Including the Potential Impact of Climate Change. Department for Environment, Food and Rural Affairs, London, UK, 2001.

165. Svensson, C. and Jones, D.A.: Dependence Between Extreme Sea Surge, River Flow and Precipitation in Eastern Britain. Int. J. Climatol. 22 (2002), pp. 1149-1168.

166. Lowe, J.A., Gregory, J.M. and Flather, R.A.: Changes in the Occurrence of Storm Surges Around the United Kingdom Under a Future Climate Scenario Using a Dynamic Storm Surge Model Driven by the Hadley Centre Climate Models, Clim. Dynam. 18 (2001), pp. $179-188$.

167. von Storch, H. and Reichardt, H.: A Scenario of Storm Surge Statistics for the German Bight at the Expected Time of Doubled Atmospheric Carbon Dioxide Concentration. J. Climate 10 (1997), pp. 2653-2662.

168. Holt, T.: A Classification of Ambient Climate Conditions During Extreme Surge Events off Western Europe. Int. J. Climatol. 19 (1999), pp. $725-744$.

169. Hadley Centre: The Hadley Centre Regional Climate Modelling System: PRECIS - Update 2002 - Providing Regional Climates for Impacts Studies, Hadley Centre, UK, www.metoffice.com/research/ hadleycentre/pubs/brochures/B2002/precis.pdf

170. Peck, S.C. and Teisberg, T.J.: International $\mathrm{CO}_{2}$ Emissions control: $\mathrm{An}$ Analysis Using CETA. Energ. Policy 23 (1995), pp. 297-308.

171. Nordhaus, W.D.: Managing the Global Commons. The MIT Press, London, UK, 1994.

172. Dowlatabadi, H. and Morgan, M.G.: A Model Framework for Integrated Studies of the Climate Problem. Energ. Policy 21 (1993), pp. 209-221.

173. Morgan, M.G. and Dowlatabadi, H.: Learning from Integrated Assessment of Climate Change. Climatic Change 34 (1996), pp. $337-368$.

174. Edmonds, J.A., Wise, M.A. and MacCracken, C.N.: Advanced Energy Technologies and Climate Change: An Analysis Using the Global Change Assessment Model (GCAM). Pacific Northwest Laboratory, Richland, Washington, 1994.

175. Richels, R. and Edmonds, J.: The Economics of Stabilizing Atmospheric $\mathrm{CO}_{2}$ Concentrations. Energ. Policy 23 (1995), pp. 373-378.

176. Alcamo, J., Kreileman, E. and Leemans, R. (eds.): Integrated Scenarios of Global Change: Results from the IMAGE 2 Model. Global Environ. Chang. 6 (1996), pp. 255-397.

177. Sokolov, A.P. and Stone, P.H.: A Flexible Climate Model for use in Integrated Assessments. Clim. Dynam. 14 (1998), pp. 291-303.

178. Carter, T.R., Parry, M.L., Harasawa, H. and Nishioka, S.: IPCC Technical Guidelines for Assessing Climate Change Impacts and Adaptations. IPCC, WMO/United Nations Environment Programme, 1994.

179. Manne, A.S. and Richels, R.G.: Buying Greenhouse Insurance: The Economic Costs of $\mathrm{CO}_{2}$ Emission Limits. MIT Press, Cambridge, MA, 1992.

180. Jones, P.D., Wigley, T.M.L. and Wright, P.B.: Global and Hemispheric Annual Temperature Variations between 1861 and 1988. Carbon
Dioxide Information Centre, NDP-022/R1. Oak Ridge National Laboratory, 1990.

181. Schneider, S.H. and Thompson, S.L.: Atmospheric $\mathrm{CO}_{2}$ and Climate Importance of the Transient Response. J. Geophys. Res. 86 (1981), pp. 3135-3147.

182. Stouffer, R.J., Manabe, S. and Bryan, K.: Interhemispheric Asymmetry in Climate Response to a Gradual Increase of Atmospheric $\mathrm{CO}_{2}$. Nature 342 (1989), pp. 660-662.

183. Schlesinger, M.E. and Jiang, X.J.: Simple-model Representation of Atmosphere-ocean GCMs and Estimation of the Timescale of $\mathrm{CO}_{2-}$ Induced Climate Change. J. Climate 3 (1990), pp. 1297-1315.

184. Batjes, J.J. and Goldewijk, C.G.M.: The IMAGE 2 Hundred Year (1890-1990) Database of the Global Environment (HYDE), 410100082. RIVM, Bilthoven, 1994.

185. North, G.R.: Theory of Energy-Balance Climate Models. J. Atmos. Sci. 32 (1975), pp. 2033-2043.

186. Wigley, T.M.L., Holt, T. and Raper, S.C.B.: STUGE: An Interactive Greenhouse Model. User's Manual. Climatic Research Unit, Norwich, 1991.

187. Legates, D.R. and Willmott, C.J.: Monthly Average Surface Air Temperature and Precipitation: Digital Raster Data on a $0.5^{\circ}$ Geographic $361 \times 721$ Grid. NCAR, Boulder, Colorado, 1989.

188. Dai, A., Wigley, T.M.L., Boville, B.A., Kiehl, J.T. and Buja, L.E.: Climates of the Twentieth and Twenty-first Centuries Simulated by the NCAR Climate System Model. J. Climate 14 (2001), pp. 485-519.

189. Delworth, T.L., Mahlman, J.D. and Knutson, T.R.: Changes in Heat Index Associated with $\mathrm{CO}_{2}$-induced Global Warming. Climatic Change 43 (1999), pp. 369-386.

190. Huth, R., Kyselý, J. and Pokorna, L.: A GCM Simulation of Heat Waves, Dry Spells, and Their Relationships to Circulation. Climatic Change 46 (2000), pp. 29-60.

191. Kothavala, Z.: Extreme Precipitation Events and the Applicability of Global Climate Models to the Study of Floods and Droughts. Math. Comput. Simulat. 43 (1997), pp. 261-268.

192. Kothavala, Z.: The Duration and Severity of Drought over Eastern Australia Simulated by a Coupled Ocean-atmosphere GCM with a Transient Increase in $\mathrm{CO}_{2}$. Environ. Modell. Softw. 14 (1999), pp. 243-252.

193. McGuffie, K., Henderson-Sellers, A., Holbrook, N., Kothavala, Z., Balachova, O. and Hoekstra, J.: Assessing Simulations of Daily Temperature and Precipitation Variability with Global Climate Models for Present and Enhanced Greenhouse Climates. Int. J. Climatol. 19 (1999), pp. 1-26.

194. Yonetani, T. and Gordon, H.B.: Simulated Changes in the Frequency of Extremes and Regional Features of Seasonal/Annual Temperature and Precipitation When Atmospheric $\mathrm{CO}_{2}$ is Doubled. J. Climate 14 (2001), pp. 1765-1779.

195. Bardossy, A. and Plate, E.J.: Modeling Daily Rainfall Using a SemiMarkov Representation of Circulation Pattern Occurrence. J. Hydrol. 122 (1991), pp. 33-47.

196. Bates, B.C., Charles, S.P. and Hughes, J.P.: Stochastic Downscaling of Numerical Climate Model Simulations. Environ. Modell. Softw. 13 (1998), pp. 325-331.

197. Hughes, J.P., Guttorp, P. and Charles, S.P.: A Non-homogeneous Hidden Markov Model for Precipitation Occurrence. Appl. Stat. 48 (1999), pp. 15-30.

198. Semenov, M.A., Brooks, R.J., Barrow, E.M. and Richardson, C.W.: Comparison of the WGEN and LARS-WG Stochastic Weather Generators for Diverse Climates. Climate Res. 10 (1998), pp. 95-107.

199. Weichert, A. and Bürger, G.: Linear Versus Nonlinear Techniques in Downscaling. Climate Res. 10 (1998), pp. 83-93.

200. Wilks, D.S.: Interannual Variability and Extreme-value Characteristics of Several Stochastic Daily Precipitation Models. Agric. Forest Meteorol. 93 (1999), pp. 153-169. 
201. Hayhoe, H.N.: Improvements of Stochastic Weather Data Generators for Diverse Climates. Climate Res. 14 (2000), pp. 75-87.

202. Trigo, R.M. and Palutikof, J.P.: Simulation of Daily Temperatures for Climate Change Scenarios Over Portugal: A Neural Network Model Approach. Climate Res. 13 (1999), pp. 45-59.

203. Mitchell, T.D., Carter, T.R., Jones, P.D., Hulme, M. and New, M.: A Comprehensive Set of High-Resolution Grids of Monthly Climate for Europe and the Globe. The Observed Record (1901-2000) and 16 Scenarios (2000-2100). J. Climate, submitted (2003).
204. Barrow, E.M. and Semenov, M.A.: Climate-change Scenarios with High Spatial and Temporal Resolution for Agricultural Applications. Forestry 68 (1995), pp. 349-360.

205. Parry, M., Park, S., Dockerty, T., Harrison, P., Jones, P., Harrington, R., Osborn, T., Rounsevell, M., Shao, J., Viner, D., Wheeler, T., Arnell, N., Butterfield, R., Park, J. and Rehman, T.: Investigation of Thresholds of Impact of Climate Change on Agriculture in England and Wales. Jackson Environment Institute Research Report 4, University of East Anglia, Norwich, UK, 136pp. 